\title{
INTEGRAÇÃO NORMATIVA PARA AVANÇOS CIENTÍFICOS COM NANOTECNOLOGIA
}

\author{
NORMATIVE INTEGRATION FOR SCIENTIFIC ADVANCES WITH NANOTECHNOLOGY
}

Loreci Gottschalk Nolasco*

Nivaldo dos Santos ${ }^{* *}$

\begin{abstract}
Resumo: Apesar dos muitos desafios propostos e ainda, dos apelos à moratórias para que governos e indústrias atentassem para a problemática gerada pelas tecnologias em convergências, como a nanotecnologia, que dos laboratórios, resultados de pesquisa ganham a indústria e se transformam em produtos e serviços que já estão à disposição para o consumo, sem que tenham sido adequadamente avaliados seus riscos à saúde humana e ao meio ambiente, e sem o devido monitoramento do descarte de resíduos, a regulamentação jurídica do uso dessa tecnologia avançou lentamente ao redor do globo, inclusive no Brasil. Após levantamento e análise da literatura, descreveu-se o desenvolvimento, aplicações e prováveis riscos à saúde de consumidores e trabalhadores e ao meio ambiente, advindas de inovações com nanotecnologia. Concluiu-se que diante da ausência de legislação específica para a matéria, o Direito brasileiro deve regulamentar a nanotecnologia pela via reflexa através da integração pelo método da analogia de diplomas aplicados às matérias de mesma ratio legis, qual seja, a proteção e a obrigação geral de segurança e a reparação integral de danos, razões que fundamentam a adoção do princípio constitucional da precaução estabelecido em diplomas de direito interno como a Lei de Biossegurança e a Política Nacional de Resíduos Sólidos, e no direito internacional, além da observância de princípios constitucionais inspiradores do sistema da analogia juris, como a dignidade humana, o respeito à vida e à saúde, os quais constituem as normas generalíssimas do sistema, como as existentes na Constituição Federal e nos Códigos.
\end{abstract}

Palavras-chave: Nanotecnologia; Inexistência de Lei específica; Integração do ordenamento jurídico brasileiro; Analogia legis; Analogia juris.

\begin{abstract}
Despite the many challenges posed and still, the appeals to moratoria for governments and industries to address the problems generated by convergence technologies, such as nanotechnology, that from laboratories, research results win the industry and become products and services that already Are available for consumption, and their risks to human health and the environment have not been adequately assessed, and without proper monitoring of waste disposal, legal regulation of the use of this technology has slowly advanced around the globe, including in Brazil. After a survey and analysis of the literature, the development, applications and probable risks to the health of consumers and workers and to the environment, coming from innovations with nanotechnology, were described. It was concluded that in the absence of specific legislation for this matter, Brazilian law should regulate nanotechnology by way of reflection through the integration by analogy of diplomas applied to subjects of the same ratio legis, that is, protection and general obligation And reasons for the adoption of the constitutional principle of precaution established in domestic legislation such as the Biosafety Law and the National Solid Waste Policy, and in international law, in addition to observing inspiring constitutional principles the system of analogy juris, such as human

* Doutora em Biotecnologia e Biodiversidade pela Universidade Federal de Goiás. Mestre em Direito pela Universidade de Brasília. Docente do Programa de Pós Graduação lato sensu em Direitos Difusos e Coletivos e da Graduação em Direito da Universidade Estadual de Mato Grosso do Sul. Coordenadora do Projeto de Pesquisa: Direito. Sociedade. Biodireito e Novas Tecnologias. E-mail: lorecign@gmail.com.

** Docente da Faculdade de Departamento de Direito Extensão Goiás, da Universidade Federal de Goiás e do Programa de Pós Graduação, nível Doutorado da Rede Pró Centro Oeste de Pesquisa e Inovação em Biotecnologia e Biodiversidade e do Mestrado em Direito Agrário, pela Universidade Federal de Goiás. Doutor e Pós-Doutor em Direito. Email: nivaldodossantos@bol.com.br.
\end{abstract}


dignity, respect for life and health, which constitute the most general norms of the system, such as those in the Federal Constitution and the Codes.

Keywords. Nanotechnology; Inexistence of specific Law; Integration of the Brazilian legal system; Analogia legis; Analogy juris.

\section{INTRODUÇÃO}

Nanotecnologia "é a compreensão e controle da matéria em dimensões de cerca de 1 a 100 nanômetros $(\mathrm{nm})$, onde os fenômenos únicos permitem novas aplicações". Nanociência e nanotecnologia são o estudo e a aplicação de coisas extremamente pequenas $\left(1 \mathrm{~nm}=10^{-9} \mathrm{~m}\right.$, ou seja, 1 nanômetro é um bilionésimo de um metro, ou um milésimo de micrômetro, tamanho de alguns átomos ou de pequenas moléculas) e podem ser usadas em todos os outros campos da ciência e tecnologia, tais como química, biologia, física, ciência dos materiais e engenharia" (US, NNI, What Is Nanotechnology?). É um campo em rápido desenvolvimento, com o potencial de revolucionar muitas áreas, incluindo eletrônicos, medicina, produção de energia e produtos de consumo.

A nanotecnologia é hoje utilizada em biologia sintética, aplicações de defesa, eletrônica, medicina (produtos farmacêuticos avançados, materiais biocompatíveis, reparação de tecidos e nervos), agricultura e produção de alimentos, produção industrial e têxtil, revestimentos de superfície, catalisadores, sensores, telecomunicações, cosméticos, bicicletas de montanha, carros e outros produtos de consumo, controle e remediação ambiental.

Segundo inventário do Project on Emerging Nanotechnologies do Woodrow Wilson International Center for Scholars (VANCE et al. 2015), havia 1.814 produtos de consumo baseados em nanotecnologia introduzidos no mercado global, por 622 empresas em 32 países, envolvendo medicina, sistema de liberação de fármacos, alimentos, cosméticos, cuidados pessoais e de higiene (a categoria saúde e fitness contém a maioria dos produtos - 762, ou $42 \%$ do total), bioenergia, dispositivos bioeletrônicos/magnéticos/optoeletrônicos. Todavia, antes mesmo que concretos estudos referentes aos potenciais riscos fossem analisados, o que, há mais de duas décadas atrás, estudos toxicológicos indicaram que seria prudente examinar e abordar as preocupações ambientais, de saúde e de segurança antes da adoção generalizada da tecnologia.

Roco et al. (2011) estimam que até 2020 serão movimentados mundialmente cerca de US\$3 trilhões e que todo o setor de semicondutores e metade do setor farmacêutico estará dependente de novos materiais contendo nanotecnologia, sendo globalmente empregados seis milhões de trabalhadores na fabricação e manuseio de nanomateriais e nanopartículas.

A Organização Internacional do Trabalho (OIT; 2010) aponta que novos e emergentes riscos no ambiente de trabalho podem ser desencadeados por novas tecnologias ou processos de produção a exemplo da nanotecnologia e da biotecnologia. Estima que é esperado que, em 2020, aproximadamente $20 \%$ de todos os produtos fabricados no mundo sejam baseados em certa medida, na utilização da nanotecnologia. Denuncia que por ser nova tecnologia, os riscos associados com o fabrico e utilização de nanomateriais são consideravelmente desconhecidos, havendo lacunas de conhecimento entre o progresso na aplicação da nanotecnologia e os seus efeitos sobre a saúde. Aponta ainda, que devido à ampla e altamente diversificada utilização de nanomateriais na indústria, é difícil estimar o número de trabalhadores expostos, os quais, enquanto são desconhecidos os 
efeitos dos novos materiais sobre a saúde e o meio ambiente, seriam susceptíveis de estarem entre os primeiros a experimentar altas taxas de exposição.

Contudo, a transformação, utilização, reutilização, reciclagem, transporte e disposição para a maioria dos nanomateriais não é atualmente regulada. Com exceção de específicos regulamentos em âmbito do Parlamento e do Conselho Europeu, da modificação do Código Ambiental Francês, e nos Estados Unidos, Berkeley/Califórnia, da alteração da norma relativa a materiais perigosos e gestão de resíduos, não há ampla normativa estatal específica em vigor, inclusive no Brasil, para tratar das regras de segurança, normalização, manuseio, estocagem, informações ao público em geral, bem como com relação à forma de prevenção/precaução e fiscalização específica, sobre riscos que podem ser gerados a partir do desenvolvimento com nanotecnologia.

Quando materiais nanoestruturados são descritos e registrados em diferentes países, não havendo regulamentação específica, incluindo o Brasil, as respectivas Agências Sanitárias o fazem em análise caso-a-caso, sob legislação aplicada aos seus equivalentes microestruturados (a granel), sem descrição mais detalhada sobre os potenciais riscos à saúde ou mesmo informações básicas sobre seu uso e manuseio seguro (HANKIN et al. 2014).

Estudos relatam que alguns nanomateriais podem simplesmente "escapar" da atenção, porque os instrumentos legais utilizados pelas agências reguladoras (exemplo da ANVISA no Brasil), para autorizar a comercialização, não abrangem produtos e suas aplicações em nanoescala, e por consequência, também os seus riscos podem não ser "capturados" de forma eficaz pela estrutura normativa vigente, normas de investigação e métodos de avaliação de risco.

O Conselho Internacional de Governança de Riscos (sigla no inglês, IRGC) (2007), aponta que a incerteza regulatória ou diferenças na regulamentação nacional em curso em algumas áreas, especialmente sobre as medidas de proteção do público, pode impedir o desenvolvimento de produtos padronizados e métodos de produção, além de dificultar a inovação industrial e a capacidade dos investidores e seguradoras em estimar os futuros ganhos, riscos e perdas, levando, inclusive, a conflitos individuais e transnacionais entre os países desenvolvidos e em desenvolvimento, surgidos a partir do foco em produtos que beneficiam principalmente os ricos, ou não abordarem as necessidades humanas mais amplas, tais como água potável, energia a preços acessíveis e conservação da biodiversidade. No comércio, essas diferenças podem conduzir à arbitragem concorrencial à medida que empresas e governos buscam vantagem pela redução das barreiras ou entraves de segurança e regulamentação para pesquisa e fabricação, ou transferindo o risco para os países com controles mais fracos.

A investigação sobre a toxicidade e biocompatibilidade não está mantendo o ritmo com a criação e introdução de novos materiais, além de ser necessária mais atenção para o acompanhamento, impacto e controle de nanomateriais no local de trabalho e no meio ambiente. Nesse caso, o Conselho Internacional de Governança de Riscos indica que governos, indústria, cientistas e organizações não governamentais em todo o mundo estão debatendo se os nanomateriais são suficientemente semelhantes a outras escalas de materiais e se podem ser regulados pelos mesmos métodos, ou se abordagens mais específicas são necessárias, em particular para estabelecer melhores práticas de avaliação de risco, de gestão e governança no que diz respeito às questões colocadas por nanoestruturas e nanossistemas ativos e mais complexos, mormente o seu potencial impacto na saúde humana e no meio ambiente (IRGC, 2007). 
Estudos e relatos científicos tem recomendado que os nanomateriais sejam tratados como se fossem substâncias inteiramente novas em relação àquelas inseridas no âmbito de regulamentação de produtos químicos, medicamentos, alimentos, cosméticos e outros temas, exigindo-se para tanto, alterações ou nova legislação. A possível necessidade de alteração da legislação para regulamentar a nanotecnologia foi abordada pelo Woodrow Wilson Center (2003), por Davies (2006), pela Real Sociedade e Real Academia de Engenharia em 2004 (UK, 2004), referenciado pelo "Livro Branco" da Environmental Protection Agency dos Estados Unidos em 2007 (US, EPA, 2007), além de outras organizações de âmbito mundial, reivindicarem legislação incluindo o princípio da precaução para os riscos nanotecnológicos.

Nessa perspectiva, na tentativa de reconhecer em seus regulamentos que nanomateriais podem representar riscos diferentes do que os materiais em escala a granel, em Maio de 2011, nos termos da legislação Toxic Substances Control Act (TSCA), a EPA emitiu "Regras de Novo Uso Significativo" para 36 substâncias químicas antes de sua fabricação, incluindo 14 nanomateriais, entre eles, nanotubos de carbono de paredes múltiplas, nanofibras de carbono de paredes múltiplas e carboneto derivado de nanocarbono.

As preocupações sobre a regulação da nanotecnologia também começam a fazer parte mais efetiva da agenda do governo brasileiro, até porque foi identificado por várias empresas, que sua ausência cria gargalos para a sua efetiva introdução nos diferentes setores industriais. Em 2013, o Comitê Interministerial de Nanotecnologia do Ministério de Ciência, Tecnologia e Inovação, aprovou a adesão do Brasil ao projeto Europeu $N A N o R E G$, que trata da regulamentação internacional em nanotecnologia, e tem como objetivos disponibilizar aos legisladores um conjunto de ferramentas de avaliação de risco e instrumentos para tomada de decisão a curto e médio prazo, garantindo a segurança de trabalhadores, consumidores e do meio ambiente. A iniciativa está ligada aos principais organismos globais que lidam com regulação, como a Organização para a Cooperação e Desenvolvimento Econômico (OCDE), a Organização Internacional para Padronização (sigla no inglês, ISO) e a Agência Europeia dos Produtos Químicos (sigla no inglês, ECHA) (BRASIL, MCTIC: 2014).

Através do método analítico de literatura especializada na área de riscos, nanotecnologia e direito, e diante da ausência de legislação específica, regulamentando a matéria, a pesquisa analisou se diplomas legais brasileiros, tratados e convenções incorporados no ordenamento jurídico, mesmo que sem menção específica, além de princípios constitucionais, em especial, o princípio da precaução, podem ser aplicados à nanotecnologia através do método de interpretação integrativa analógica, a partir de leis como da Biossegurança $n^{\circ}$. 11.105/2005; da Política Nacional de Resíduos Sólidos no . 12.305/2010; de Atividades Nucleares nº. 6.453/1977 (responsabilidade civil objetiva e agravada), da Política Nacional sobre o Meio Ambiente e Mudanças Climáticas nº 12.187/2009 (exigir a implantação de medidas precaucionais de segurança de imediato), da Lei $\mathrm{n}^{\circ}$. 11.934/2009 que trata da exposição humana a campos elétricos, magnéticos e eletromagnéticos, do Código de Defesa do Consumidor (direito à informação e rotulagem) e do Código Civil (responsabilidade civil objetiva). 


\section{POSSIBILIDADES ADVINDAS DO USO DA NANOTECNOLOGIA}

Os potenciais avanços e desempenhos da nanotecnologia, levantam questões e apresentam desafios consideráveis e significativos às estruturas e processos de governança, aos reguladores, fabricantes e, em última instância, para a sociedade em geral, muito mais complexos e de longo alcance do que muitas outras inovações, em especial quanto a saber como os nanomateriais podem interagir com outros sistemas humanos e biológicos, com implicações nas esferas sociais, econômicas, políticas, éticas, legais e ecológica. Uma grande preocupação é que as técnicas para medir e prever o comportamento e controle de partículas, dispositivos e sistemas em nanoescala são ainda relativamente imaturas, e, portanto, seus impactos de longo prazo são imprevisíveis (IRGC, 2006; 2007).

As diferentes propriedades físico-químicas em comparação com o seu respectivo material em escala macro, incluem propriedades ópticas, magnéticas, comportamento térmico, resistência do material, solubilidade, condutividade, atividade catalítica (BURLESON et al. 2004), aumento da integridade estrutural ou alteração da atividade química ou biológica (ROCO et al. 2012), levando a efeitos surpreendentes e unpredicted (que não é previsto), ou unpredictable (que é incapaz de ser previsto) (IRGC: 2006).

Um exemplo clássico desse efeito é visto com o ouro. Em macro escala, o metal é normalmente inerte, já o material nanoparticulado de ouro, é altamente reativo e, por isso, útil para aplicação em exames de imagens e biodistribuição de fármacos. O mesmo acontece com nanopartículas de dióxido de titânio $\left(\mathrm{TiO}_{2}\right)$, normalmente consideradas como materiais inertes, na faixa nano podem se tornar reativas devido à redução de tamanho (BORM: 2002; DECHSAKULTHORN et al. 2008). Isso faz com que os estudos nanotoxicológicos de nanomateriais sejam mais complexos (CANELAS et al. 2009; HARPER et al. 2011).

De acordo com Donaldson et al. (2004) e Arora et al. (2012), as nanopartículas são mais propensas a interagir com as células e os vários componentes biológicos e serem distribuídos no organismo, o que aumenta suas chances de interagir com diversos órgãos e ativar respostas inflamatórias e imunológicas. Não existe interação somente com a célula, mas com todas as estruturas biológicas que podem estar no percurso da nanopartículas, desde a sua administração até a sua eliminação.

Nanomateriais podem combinar-se com ferro ou outros metais, aumentando o nível de toxicidade em comparação com a mesma massa das partículas equivalentes, convencionais e maiores (RENN et al. 2006; DROBNE, 2007; LAI et al. 2010; MCINTYRE, 2012) com riscos desconhecidos, além de suscitarem particular preocupação por causa das características desconhecidas de suas novas propriedades e seu uso potencial em quantidades concentradas (IRGC, 2007). Uma vez no corpo, alguns tipos de nanomateriais podem atravessar as membranas celulares, e viajar diretamente no sistema circulatório e olfativo, ou translocar para outros órgãos (cérebro, fígado, rins, sistema nervoso central) (NIOSH, 2013; RAJ et al. 2012).

Diante de incertezas associadas com a avaliação do risco de exposição humana para recomendar com precisão os limites de exposição para formatação de normas e regulamentos, precauções estritas são recomendadas, para evitar os possíveis efeitos adversos para a saúde decorrentes da exposição a nanomateriais (BAKAND et al. 2012). 
Muitos documentos e relatórios científicos internacionais discutindo riscos e governança da nanotecnologia, informam a necessidade de adoção do princípio da precaução e de nova legislação para a área. A Comissão Quebec (2006) recomenda que sua utilização é fundamental para a regulamentação da nanotecnologia em face das incertezas, em especial para evitar ocorrência de danos. $\mathrm{Na}$ Europa, em inserção constitucional (não apenas legal), a França dispôs sobre o princípio da precaução no artigo 5\%, da Charte de 2003, determinando que, "quando a ocorrência de um dano, ainda que incerto diante do estágio do conhecimento científico, possa afetar de modo grave e irreversível o meio ambiente, as autoridades públicas providenciarão, através da aplicação do princípio da precaução e nas áreas de suas atribuições, a implementação de procedimentos de avaliação de riscos e a adoção de medidas provisórias e proporcionais com a finalidade de evitar a ocorrência de danos" (MATHIEU et al. 2004; ROMI, 2004).

O Instituto Nacional para a Segurança e Saúde Ocupacional (NIOSH: 2010) dos Estados Unidos apoia a iniciativa precaucional e de hierarquia tradicional de controles, oportunizando às empresas empregarem a estratégia da Prevention through Design (PtD), também aplicável na gestão de riscos de nanomateriais durante a fase de projeto, desde os estágios iniciais de concepção, planejamento e desenvolvimento do processo ou instalação, com métodos de trabalho e operações, processos, equipamentos, ferramentas, produtos, novas tecnologias e a organização do trabalho, procurando reduzir a exposição, antecipar e evitar a ocorrência de riscos potenciais decorrentes da nanotecnologia (SCHULTE et al. 2008; OSTIGUY et al. 2009; MONIZ, 2013; KREIDER, 2013).

A Real Sociedade e Real Academia de Engenharia do Reino Unido em 2004 (UK, 2004) e a Agência Federal do Meio Ambiente da Alemanha em 2009 (ALEMANHA: 2009), reconhecendo a importância da nanotecnologia na concepção de novos produtos que poderão ter efeitos benéficos no ambiente e na economia, sublinharam a necessidade de observância do princípio da precaução e da obrigatoriedade do registro de produtos resultantes da nanotecnologia, exigindo-se a "criação de um quadro legal para lidar com a segurança de materiais obtidos com a tecnologia, pois seus eventuais riscos para a saúde ainda não foram suficientemente investigados, apesar de estarem cada vez mais disseminados no solo, na água e na atmosfera", e de "ensaios de laboratório efetuados em ratos terem revelado que nanopartículas se instalam nas células, causando danos na informação genética e doenças idênticas às causadas pelo amianto, que, só muito depois de ter revolucionado o mercado da construção, se revelou cancerígeno" (MASSADA: 2010).

\section{GESTÃO PRECAUCIONAL DE RISCOS NANOTECNOLÓGICOS: O PRINCÍ- PIO CONSTITUCIONAL DA PRECAUÇÃO}

Ao dispor sobre as exigências previstas no art. 225, $\S 1^{\circ}$, V, da Constituição Federal de 1988 (CF/1988), o Estado brasileiro reconheceu que vivemos em uma "sociedade de risco" (BECK, 2010), exigindo-se a criação de mecanismos de controle como aqueles arrolados na Lei de Política Nacional do Meio Ambiente, precisamente o procedimento de Licenciamento Ambiental, em que os órgãos ambientais competentes, baseados em laudos técnicos (comunicações interdisciplinares), definem critérios e ações preventivas e compensatórias para concessão da autorização administrativa. Com isso, a Constituição incumbiu o Poder Público de controlar o emprego de técnicas que 
comportem riscos para a vida, à qualidade de vida e ao meio ambiente, exigindo explicitamente a implementação de medidas de precaução (exemplo, Estudo Prévio de Impacto Ambiental), e de forma implícita assegurou a aplicação do instituto da responsabilidade civil prospectiva (futuras gerações), fundado no princípio da dignidade da pessoa humana (arts. $1^{\circ}$ e 170 ).

Três são os bens jurídicos (direitos fundamentais) expressamente tutelados no que se refere à nanotecnologia: a vida, a saúde e o meio ambiente. Todos com supedâneo na $\mathrm{CF} / 1988$ e com perspectiva intergeracional (princípio da equidade intergeracional), a exemplo da proteção ambiental estabelecida para as presentes e futuras gerações no artigo 225, caput, que, numa relação intratemporal e intertemporal, fundamenta a aplicação do princípio da precaução voltada para uma amplitude temporal (prospectiva), envolvendo o princípio da solidariedade entre gerações ou da responsabilidade de longa duração, impositiva da equidade entre pessoas vivas no presente e pessoas que nascerão no futuro, como pilar do desenvolvimento sustentável (reconhecido como princípio da Ordem Econômica na CF/1988, art. 170, VI) e do Direito Ambiental.

Com todo sistema jurídico socioambiental global preocupado com questões referentes à proteção do meio ambiente, o Estado se vê impulsionado a lançar programas que influenciem meios alternativos de preservação, como por exemplo, através do incentivo ao desenvolvimento tecnológico voltado para o enfoque ambiental.

A Convenção do Clima realizada durante a Conferência das Nações Unidas para o Ambiente e Desenvolvimento, no Rio de Janeiro em 1992 (ONU, 1992, p. 409), trouxe um importante avanço ao abordar e conceituar as Tecnologias Ambientalmente Amigáveis (do inglês Environmentally Sound Technologies) como sendo aqueles processos e produtos que geram poucos ou nenhum resíduo, protegem o meio ambiente, são menos poluentes, utilizam todos os recursos de uma forma mais sustentável, reciclam mais resíduos e produtos, e tratam os dejetos residuais de uma maneira mais aceitável.

Santos et al. (2014) informam que a crescente busca por alternativas que visam aliar o desenvolvimento econômico com a preservação ambiental, ampliou a necessidade de criação de tecnologias verdes. As tecnologias ambientais podem ser caracterizadas como aquelas que possibilitam inovações nos procedimentos e na criação de produtos capazes de diminuir consideravelmente ou eliminar impactos degradantes ao meio em que são aplicadas. Por meio do Instituto Nacional de Propriedade Industrial (INPI), com objetivo de aliar a inovação e a proteção do meio ambiente, em abril de 2012 o Brasil lançou o Programa Piloto de Patentes Verdes, encerrando sua terceira fase em 16 de abril de 2016. A partir de 06 de dezembro de 2016, o INPI passou a oferecer o exame prioritário de pedidos relacionados a tecnologias verdes como serviço (BRASIL, INPI).

A inovação e as transformações tecnológicas são então a chave para a busca do desenvolvimento sustentável. Para que isto se dê, é crucial que se busque um modelo de gestão que contemple: viabilidade econômica, inclusão com justiça social e equilíbrio ambiental.

A nanotecnologia, juntamente com outras tecnologias emergentes que oferecem soluções poderosas e revolucionárias, como o genoma, a biomimética, a tecnologia da informação, a energia renovável, é apontada como motivador global da sustentabilidade (HART et al. 1999; 2004). Representam, com isso, a oportunidade para as empresas de, em vez de simplesmente buscar reduzir os impactos negativos de suas operações, esforçarem-se para solucionar problemas sociais e 
ambientais por meio do desenvolvimento ou da aquisição de novas capacitações, que se direcionam diretamente para os desafios da sustentabilidade (MCDONOUGH et al. 2002).

Por exemplo, a biotecnologia e a nanotecnologia criam produtos e serviços a um nível molecular, sustentando o potencial para eliminar o conceito de resíduo e poluição (DREXLER: 1986; 2006). Similarmente, a biomimética representa uma tentativa de ultrapassar os processos naturais a fim de criar novos produtos e serviços sem ter de depender da força bruta para arrasar grandes reservas de matérias-primas naturais (BENYUS: 1997). A tecnologia da informação e a energia renovável são distribuídas em caracteres, o que significa que podem ser aplicadas nos contextos mais remotos e em pequena escala, eliminando a necessidade de infraestruturas centralizadas e de distribuição por cabos, ambos ambientalmente nocivos (CHRISTENSEN et al. 2001). As tecnologias de distribuição têm, portanto, um potencial de atender às necessidades de bilhões de habitantes rurais (que até agora têm sido ignorados pelos negócios globais) de modo a reduzir drasticamente o impacto ambiental (COYLE: 2001).

Razão disso, em Março de 2016, os Estados Unidos através da Iniciativa Nacional de Nanotecnologia (do inglês, National Nanotechnology Initiative), comunicou o lançamento da "Iniciativa de Assinatura em Nanotecnologia: Sustentabilidade da Água através da Nanotecnologia: soluções em nanoescala para um desafio de escala global”, objetivando aproveitar as propriedades únicas de nanomateriais artificiais (o pequeno tamanho, a área de superfície e a reatividade aumentada quando a sua dimensão cai abaixo de cerca de $100 \mathrm{~nm}$ ), e gerar avanços significativos no desenvolvimento de soluções tecnológicas, que podem aliviar tensões atuais no abastecimento de água e fornecer métodos para utilizar de forma sustentável, os recursos hídricos no futuro em todo globo (US, NNI: 2016).

Nesse sentido, a aplicação da nanotecnologia estaria voltada para resolver problemas ambientais e de saúde, como uma importante "ferramenta" de melhoria da qualidade ambiental e da vida humana, portanto de promoção do desenvolvimento sustentável. Vê-se o potencial que a tecnologia pode proporcionar no desenvolvimento de nações (Estados) o que também poderá gerar benefícios diretos ao desenvolvimento da sociedade, incluindo o meio ambiente como um todo.

Tarrega e Oliveira (2007; p. 364) asseveram por outra via: “A problemática referente à tecnologia consiste no fato de que ela sempre teve ligada ao saneamento das preocupações de ordem econômica, como a competitividade, o investimento e as pressões de mercado. Dentro desse contexto, sempre houve certa desconfiança pelos ambientalistas em relação às promessas da inovação", contudo, a partir dos anos 70, "foi crescente o investimento em tecnologias limpas ou alternativas como resposta a pressões dos movimentos ambientalistas e da própria sociedade, à medida que estes perceberam que o progresso tecnológico pode ter aplicações emancipatórias no que tange à busca do desenvolvimento sustentável".

A partir disso, para que tecnologias cumpram objetivos importantes em relação ao desenvolvimento com sustentabilidade, será preciso que o desenvolvimento tecnológico seja acompanhado do desenvolvimento de novas técnicas, para identificar e responder aos riscos incertos, opondo-se ao atual quadro de decisões políticas na maioria das vezes reativas e com o enfoque nos resultados no curto prazo. Embora não seja o único ator a determinar os rumos do complexo desenvolvimento da nanotecnologia, o Estado pode influenciar nesse processo, pois conserva mesmo em tempos 
de globalização um papel fundamental como financiador e regulador das atividades de pesquisa e desenvolvimento tecnológico.

Nesse cenário, dois instrumentos passaram a protagonizar a gestão dos "novos danos", ${ }^{1}$ a saber, os já bem conhecidos princípios da prevenção e da precaução. Ambos estabelecem mecanismos voltados ao evitar e não ao reparar, mas a ideia de precaução é particularmente mais ampla. A precaução como princípio surge na Alemanha (Vorsorgeprinzip). Vorsorge vem a ser mais do que um simples "dever de cuidado" (sorgfaltspflicht). Ele estabeleceu, assim, um paradigma novo para dar uma proteção ex ante, a interesses de ordem coletiva ou futuros. Um "simples" perigo, ainda que sem provas científicas conclusivas, já estaria a autorizar a adoção de medidas jurídicas para impedir que o próprio dano deixe de acontecer.

Com isso, surge uma nova contextualização para o tema da responsabilidade civil, lastreada na chamada "obrigação de segurança” (VINEY: 2008). Até então, a responsabilidade civil abrangia apenas a relação entre os seres humanos. Agora, numa perspectiva prospectiva, abarca os interesses das futuras gerações, com o propósito de manter as condições de possibilidade de realização da pessoa humana e de desenvolvimento das suas capacidades (Responsabilidade épica, de esperança) (LOUREIRO: 2010), a Constituição de 1988 estabeleceu em várias cláusulas espalhadas ao longo de seu texto, enunciados como a proteção ambiental para as presentes e futuras gerações delineada no artigo 225, caput, ${ }^{2}$ que imputa, "sob o pálio de uma perspectiva prospectiva da responsabilidade, um dever ao Estado e à coletividade, em defender e preservar o meio ambiente para as presentes e futuras gerações, estabelecendo, em última instância, não um sentido setorial, adstrito ao universo ambiental, mas de teor geral e generalizante basilar na relação intergeracional do tecido social”.

É dizer, o enunciado do dispositivo Constitucional, não serve apenas de paradigma normativo à proteção ambiental, mas a todas as esferas que se projetem para o futuro, e representem algum risco de dano imprevisível ou incerto (FERREIRA: 2011).

Canotilho (2010) explica que o que está em causa, é que a inclusão dos interesses das gerações futuras (solidariedade entre gerações) nos princípios materiais de atuação político-constitucionalmente relevantes, ganhe efetividade e operacionalidade prática, e, isso pressupõe logo, como ponto de partida, a efetivação do princípio da precaução. O princípio, configurado como "verdadeiro princípio fundante e primário da proteção dos interesses das futuras gerações é quem impõe prioritariamente e antecipadamente a adoção de medidas preventivas e justifica a aplicação do instituto da responsabilização e da utilização das melhores tecnologias disponíveis".

Isso porque, como atestam Santos e Romeiro (2007; p. 117-8) “O desenvolvimento tecnológico conduzido pela economia da globalização e livre comércio ainda constitui entrave ao modelo de progresso técnico sustentável”. E ainda, "O progresso tecnológico aliado a um crescimento demográfico sem precedentes trouxe riscos de exploração excessiva dos recursos e destruições irreversíveis ao patrimônio natural”. Necessário, para tanto, que a proteção ambiental seja em "grande parte obtida através do desenvolvimento de técnicas adequadas". Nesse caso, "Mesmo com a norma para utilização da melhor tecnologia independente do estado concreto do bem ambiental a ser protegido, e mesmo com o princípio da precaução, o Estado deve atuar com proibições e restrições, ainda que o potencial danoso de um determinado material não esteja provado".

O princípio da responsabilização, ao implicar a assunção das consequências pelos agentes causadores de danos ao ambiente, significa imputação de custos e obrigação de medidas de com- 
pensação e de recuperação que conduzirão à consideração, de forma antecipativa, dos efeitos imediatos ou a prazo das respectivas atuações ambientalmente relevantes.

Ferreira (2011) aduz que no Brasil, um dos berços constitucionais onde se acha descansada a responsabilidade de índole prospectiva, reside no art. $1^{\circ}$, III, do texto fundamental, que trata da dignidade da pessoa humana, havendo "margem para se edificar uma razão transversal que ligue todas as ideias particulares de responsabilidade setorial a uma teoria geral da responsabilidade prospectiva, alicerçada nas lógicas do futuro e da prevenção de riscos incertos e imprevisíveis”, como é o caso da nanotecnologia.

Destaca-se que a nanotecnologia é de certa forma, conflito de exigência de responsabilidades sob o foco prospectivo, porque, diferentemente dos riscos antigos, perceptíveis mediante os sentidos, os riscos atuais decorrentes das inovações tecnológicas, nelas a biotecnologia e a nanotecnologia, são invisíveis porque ficam embuçados numa esteira de fórmulas químico-físicas. Significa dizer que são imperceptíveis, e até mesmo imprevisíveis num tempo imediato, pois no futuro podem ou não gerar danos às pessoas ou ao meio ambiente, fazendo-nos compreender que manipulações com nanotecnologia, respondam por danos remotos (futuros), até mesmo os imprevisíveis, e, com isso, afastar-se, explicitamente do regime de direito comum, ou seja, da interpretação que se conferia a tal regime no que tange aos assim chamados danos diretos e imediatos.

Vê-se claramente uma comunicação entre direitos constitucionais, que se unem para promover a segurança jurídica almejada do desenvolvimento na escala nano, ainda que não se tenha notícia de qualquer regime jurídico específico aplicável ao tema no Brasil, e na quase totalidade do globo. Esses ditames constitucionais devem pautar as decisões econômicas de forma sustentável e socialmente responsável, especialmente, sem perder de vista que, a partir de 1988 e consolidando-se em 2002, com o Código Civil brasileiro, a teoria jurídica da empresa não comporta mais um sistema exploratório descompromissado com o alcance dos efeitos sociais da atividade empresarial.

Nessa perspectiva, de um lado, a CF/1988 assegura direitos fundamentais à liberdade de pesquisa científica e, de igual forma, o direito à vida, à saúde e ao meio ambiente, sadio e ecologicamente equilibrado, garantido às presentes e às futuras gerações. Tendo em vista a supremacia Constitucional dos direitos e garantias positivados no corpo de Constituições rígidas, como a Brasileira de 1988 e do princípio da legalidade, a que todos os poderes estatais (Executivo, Legislativo e Judiciário) estão submetidos (FERRAJOLI: 2012), inclusive a Ciência, urge a instrumentalização efetiva (garantia material) desses direitos a todos os indivíduos, que no viés garantista (baseada no respeito à dignidade da pessoa humana e seus direitos fundamentais, com sujeição formal e material das práticas jurídicas aos conteúdos constitucionais), limitam e vinculam governos, agências governamentais, indústrias, cientistas, laboratórios, universidades e demais partes interessadas no desenvolvimento da nanotecnologia, vedando-lhes ou lhes impondo determinados conteúdos.

Na prática, a Constituição não pode ser vista e muito menos aceita como mera ou simples "folha de papel" e nem mesmo como pura decorrência dos "fatores reais do poder que regem uma nação" (LASSALE: 2000; p. 10-11). Isso porque a Constituição deve ser respeitada e acatada por todos os componentes do Estado (governantes, sociedade civil, indústrias, empresários, cientistas, laboratórios etc.), diante da força normativa que dela decorre (HESSE: 1991; p. 25). 
Como constatou o Relator Ministro Dias Toffoli do Supremo Tribunal Federal, por ocasião do julgamento do Recurso Extraordinário 627.189 do Tribunal de Justiça de São Paulo (BRASIL, STF: 2016) sobre o alcance do campo eletromagnético de linhas de transmissão e distribuição de energia da Eletropaulo: o princípio da precaução resulta da constatação de que a evolução científica traz consigo riscos, muitas vezes imprevisíveis ou imensuráveis, o que acaba por exigir uma reformulação das práticas e procedimentos tradicionalmente adotados na respectiva área da ciência, mormente porque para a ciência não existe - em um contexto amplo - um nível de risco igual a zero, como adverte Winter (1996): os riscos não podem ser excluídos, na medida em que sempre permanece a probabilidade de um dano menor, ou seja, os riscos sempre existirão mas podem ser minimizados. Nessa perspectiva, o princípio constitucional da precaução "é um critério de gestão de risco a ser aplicado sempre que existirem incertezas científicas sobre a possibilidade de um produto, evento ou serviço desequilibrar o meio ambiente ou atingir a saúde dos cidadãos".

E mais, - continua o Ministro -, exige que "o Estado analise os riscos, avalie os custos das medidas de prevenção e, ao final, execute as ações necessárias" (imposição de controle, avaliação e fiscalização de processos, serviços e produtos com nanotecnologia, pautados de acordo com os parâmetros de segurança reconhecidos internacionalmente), "as quais serão decorrentes de decisões universais, não discriminatórias, motivadas, coerentes e proporcionais". Cabendo dizer, ao cabo, que conforme referido na comunicação da "Comissão Europeia sobre o princípio da precaução" de 2000, em seu Ponto 5: a decisão sobre o que é um risco aceitável para a sociedade é eminentemente uma responsabilidade política (do Estado).

Percebe-se com isso, a necessidade do emprego de processos democráticos de decisão e acompanhamento das ações, com transparência e amplo acesso às informações com vistas a proporcionar a participação da sociedade na tomada de decisão.

Em âmbito jurídico-político-administrativo, Berger Filho et al. (2012) mencionam como medidas de precaução aos riscos de nanomateriais:

A) O controle e o monitoramento constante dos riscos e do impacto das diferentes aplicações da nanotecnologia ao longo de seu ciclo de vida, pelos laboratórios e fabricantes de produtos e serviços. Isso pode ser concretizado por meio da exigência legal-administrativa de estudos prévios de avaliação científica por órgãos governamentais, que avaliem a veracidade das informações e o impacto do produto ou processo sobre a segurança dos nanomateriais, antes e depois de sua comercialização.

O gerenciamento e a avaliação desse controle e o monitoramento, podem ser complementados através de iniciativas voluntárias de autorregulação, de ocorrência instrumentalizada através de guias de melhores práticas, certificações, códigos de conduta desenvolvidos por instituições privadas como associações profissionais, organizações voltadas para a padronização técnica, institutos de pesquisa, corporações transnacionais ou organizações não governamentais, entre as quais: o DuPont \& Environmental Defense (Nano Risk Framework); NanoSAFE Framework (parceria entre governo e universidades americanas); Code of Conduct for Responsible Nanosciences and Nanotechnologies Research (recomendado pela Comissão das Comunidades Europeias, como código voluntário estabelecido no âmbito da União Europeia); Basf Code of Conduct Nanotechnology; Multi-Stakeholder Codes of Conduct (Responsible NanoCode); Guide de bonnes pratiques 
Nanomatériaux et HSE (elaborado em conjunto com a Fédération Française pour les sciences de la Chimie com a l'Union des Industries Chimiques);

B) A exigência de comunicação obrigatória de informações sobre os riscos e o impacto ambiental de produto ou processo, tal como fez a França quando da modificação do seu Código do Ambiente (Code de l'environnement) em 2012, nos termos do Decreto ${ }^{\circ}$. 2012-232 que acrescentou capítulo específico para tratar da "Prevenção de riscos à saúde e ao ambiente decorrente da exposição a substâncias no estado de nanopartículas". Somado a isso, também merece destaque a questão da exigência de "rotulagem dos produtos que contenham nanopartículas sintéticas livres", enquanto instrumentos de garantias do nível adequado de proteção da saúde humana e do meio ambiente.

Além da França, some-se a mudança em 2011, da legislação americana Toxic Substances Control Act (TSCA) pela Environmental Protection Agency (EPA), exigindo notificação pré-fabricação de 14 nanomateriais, considerando-os como produtos químicos novos. Destaca-se ainda aprovação específica pelo Parlamento Europeu e o Conselho em 2012 (EUROPEAN PARLIAMENT AND COUNCIL: 2012) de regulamentação para biocidas quando esses usam nanomateriais; fato já ocorrido em 2009 para cosméticos (EUROPEAN PARLIAMENT AND COUNCIL: 2009). Com isso, torna-se o primeiro órgão governamental nacional ou supranacional a estabelecer exigências, obrigatórias e específicas, incluindo disposições relativas à rotulagem (uso de etiquetas detalhando o conteúdo), e o informe às autoridades antes do lançamento ao mercado de produtos contendo nanomateriais. Algo similar é exigido para informar aos consumidores o conteúdo de nanopartículas manufaturadas nas etiquetas de alimentos que as contenham (EUROPEAN PARLIAMENT AND COUNCIL, 2011).

Impõe-se, um esforço para evitar a toxicidade inerente na fase inicial do projeto, entender os riscos apresentados ao longo do ciclo de vida de produtos, processos e serviços decorrentes da tecnologia, utilizar os processos democráticos de deliberação, divulgação, garantindo o valor fundamental da segurança por meio de avaliação de seus resultados, soluções e instrumentos que promovam consenso e satisfação das expectativas entre as diversas partes envolvidas (ENGELMANN: 2011).

Mas como visto o Estado brasileiro ainda não regulamentou especificamente a matéria da nanotecnologia, que, como analisado, apresenta especificidades que outras áreas já reguladas por lei não apresentam, em especial pelo reduzido tamanho (1 a $100 \mathrm{~nm}$ ), nanopartículas e partículas ultrafinas, alteram as propriedades óticas, físicas, térmicas, mecânicas e elétricas, assim como têm uma área de superfície elevada disponível para realizar reações de adsorção, ou aumentar a reatividade química e a potencialidade tóxica, podendo levar a efeitos imprevisíveis ao longo da cadeia produtiva, desencadeando riscos e danos para pessoas humanas (presentes e futuras gerações) e o meio ambiente.

Por entender que a nanotecnologia não é suficientemente regulamentada pelo Estado brasileiro, uma vez que a legislação pertinente a outras matérias de interesse e importância análogos (como da biossegurança, resíduos sólidos e acidente nuclear, em especial por estabelecerem exigências de adoção de medidas de precaução para evitar ou minimizar ao máximo riscos e danos em geral à saúde humana e meio ambiente), pode apenas parcialmente atender alguns aspectos da nanotecnologia, pautamos ser imprescindível que o Poder competente legisle sobre o tema. 
Mormente, pelo fato da nanotecnologia envolver em suas aplicações, processos e utilizações, direitos fundamentais (saúde, vida e meio ambiente), como direitos individuais relevantes para o sistema jurídico-legal, o intérprete deverá solucionar demanda judicial suprimindo a lacuna legal de acordo com o que dispõe o próprio ordenamento jurídico, ou mesmo o empreendedor ou investidor na área deverá agir de maneira a observar e fazer prevalecer os direitos fundamentais dos envolvidos, tanto no processo industrial de síntese e fabricação (trabalhadores), quanto nos resultados finais (consumidores e meio ambiente) da comercialização ao descarte de resíduos.

A obrigação de julgar leva o juiz a entender, interpretar e aplicar o direito como uma totalidade. Nos dizeres de Espínola, apud Maximiliano (1965; p. 18), “interpretação é a declaração precisa do conteúdo e do verdadeiro sentido das normas jurídicas". Para Maximiliano (1965, p. 6), "a aplicação do direito consiste no enquadrar um caso concreto em a norma jurídica adequada. Submete às prescrições da lei uma relação da vida real; procura e indica o dispositivo adaptável a um fato determinado. Por outras palavras: tem por objeto descobrir o modo e os meios de amparar juridicamente um interesse humano". E, cada vez mais, o direito volta ao princípio napoleônico de que não pode haver recusa sob o pretexto de silêncio, obscuridade ou insuficiência da lei. Essa obrigação de julgar, gera para o indivíduo um direito subjetivo de encontrar solução, oferecida pelo Estado por meio do Judiciário, ao caso concreto litigioso.

\section{INTERPRETAÇÃO E INTEGRAÇÃO DO ORDENAMENTO JURÍDICO}

No que respeita às inovações contendo nanotecnologia, que ainda não foram regulamentadas por lei específica pelo Estado brasileiro, somado ao fato de que legislações pertinentes a outras matérias de interesse e importância análogos, parcialmente atendam a alguns aspectos da tecnologia, entende-se estar diante da problemática em torno de incompletude e de lacuna na lei. No direito pátrio, o art. 140 (antigo artigo 126) do recente Código de Processo Civil (CPC, Lei 13.105/2015), o art. $4^{\circ}$ da Lei de Introdução às Normas do Direito Brasileiro (LINDB) e outras previsões legais, admitem a existência de lacuna na lei, tanto é que já trazem as técnicas para que o magistrado possa resolvê-la. O art. 5, XXXV, da CF/1988 dispõe que "a lei não excluirá da apreciação do Poder Judiciário lesão ou ameaça a direito", conferindo a todos o direito de demandar judicialmente. Assim, há a necessidade de os juízes julgarem qualquer lesão ou ameaça de lesão a direitos, mesmo que não exista uma lei prevendo o caso.

Nesse caso, a integração de uma lacuna não se situa no plano legislativo e não chega a ser uma atividade legislativa do magistrado, pois ele não cria novas normas jurídicas gerais, mas individuais, para solucionar aquele caso concreto e, consequentemente, obedecer ao princípio da proibição do non liquet (o poder de o juiz não julgar, por não saber como decidir). Dessa forma, a função de legislar continua sendo atividade típica do Poder Legislativo.

A lacuna legislativa é uma fatalidade, dizia Oliveira Ascensão (1991; p. 355, 368-416), podendo ocorrer por deficiência de técnica legislativa, por intenção de não regular a matéria e por imprevisibilidade. Entretanto, qualquer que seja a razão de sua existência, ocorrendo a lacuna, é necessário que seja suprida para resolver o caso concreto. Seguramente, será diferente a solução para colmatá-la (preenchê-la), se a lacuna for intencional ou causada por imprevisibilidade, mas há de se 
fazê-lo em qualquer hipótese. Para tanto é dever jurídico a sua integração pelo Estado. Quer dizer, o próprio sistema jurídico tem que desenvolver mecanismos internos que garantam essa integração.

Streck (2007; p. 104-5) ressalta a importância da discussão em torno da existência ou não de lacunas, em especial, porque "pode-se entender, sem dúvida, que, quando o juiz está autorizado/ obrigado a julgar nos termos dos arts. $4^{\circ}$ da LICC e 126 do CPC (isto é, deve sempre proferir uma decisão), isso significa que o ordenamento é, dinamicamente, completível, através de uma auto-referência ao próprio sistema jurídico".

No direito comparado, Castanheira Neves (1993; p. 207 e segs.) pontifica que as lacunas são um fenômeno que revela "a insuficiência do direito positivo constituído para dar resposta às exigências da realização concreta da juridicidade". Também em terras portuguesas, Cabral de Moncada (1995; p. 161 e segs.) diz que a lacuna "é um vazio da lei ou dum sistema de leis, na previsão e regulamentação da vida jurídica real e seus casos particulares". Pauta-se que não se admitem lacunas no direito, mas na norma positivada, pois o defeito não é da ciência, mas do ordenamento e das suas normas jurídicas. Lacuna seria então, ausência de norma reguladora para um caso concreto específico, ou quando a aplicação de uma norma existente no ordenamento se mostrar indesejável.

Pode-se dizer que a nanotecnologia situa-se em ambas as hipóteses, sendo claro que não possui normatização específica, acresça-se que regulamentações de outras matérias como medicamentos, alimentos, cosméticos e substâncias químicas em geral, podem não ser desejáveis, nesse caso, podem conter prescrições a menos no tocante aos riscos nanotecnológicos, o que, todavia, não inviabiliza a aplicação a alguns aspectos da tecnologia. Em outras palavras, normativas não específicas prescrevem diretrizes gerais e parciais sobre a matéria, devendo o Poder Legislativo regular as especificidades e particularidades, atendendo os interesses de todas as partes envolvidas, do governo, indústria, cientistas, trabalhadores, consumidores, e o meio ambiente.

\section{PREENCHIMENTO DE "LACUNA" LEGAL DA NANOTECNOLOGIA. ANA- LOGIA LEGIS E ANALOGIA JURIS.}

O caráter da coerência e o da completude estão ligados estreitamente entre si, mesmo que tal conexão não seja sempre evidente. Savigny (2009; p. 267) assim formula as relações entre esses dois caracteres:

[...] unidade e completitude ... O procedimento ordinário consiste em trazer do conjunto das fontes um sistema de direito ... Falta a unidade, e agora se trata de remover uma contradição; falta a completitude, e agora se trata de colmatar uma lacuna. Na realidade, porém, estas duas coisas podem se reduzir a um único conceito fundamental. Aquilo que procuramos estabelecer é sempre a unidade: a unidade negativa de afastar as contradições; a unidade positiva de preencher as lacunas.

Carnelutti, em sua Teoria Geral do Direito (1999; p. 106), exprime a relação existente entre coerência e completude do ordenamento, afirmando que o direito pode apresentar dois vícios: um vício por excesso (exuberância), quando há mais normas do que deveria haver (na incoerência há duas normas contraditórias, das quais somente uma pode estar contida no sistema); e um vício por falta (deficiência), quando há uma norma a menos, no caso de lacuna. No primeiro caso, o trabalho 
do jurista consiste na purgação do ordenamento jurídico (isto é, no eliminar a norma em excesso); no segundo caso consiste na integração do próprio ordenamento.

Concluindo: a incoerência do sistema é a situação em que "há" uma norma e "há" outra norma incompatível com a primeira; a incompletude é a situação em que não há "nem” uma norma, "nem” uma outra norma incompatível com essa. Na incoerência há uma norma a mais (há ... há); na incompletude há uma norma de menos (nem ... nem).

A existência de lacunas, segundo Bobbio (2011; p. 130-1) em sua Teoria Geral do Direito, caracterizaria a incompletude do ordenamento, dado o vício por falta (deficiência), quando há uma norma a menos, no caso de lacuna da lei, compreendida em certo sentido como formulação incompleta da vontade do legislador, caso em que consistirá o trabalho do intérprete em fazer a integração do próprio ordenamento, por parte da jurisprudência, destacando, no entanto, que tal integração não é uma atividade qualitativamente diferente da interpretação (não é, portanto, uma atividade criativa), mas, ao contrário, é uma species particular do genus interpretação. Nesse sentido Bobbio fala de interpretação integrativa, para indicar que a integração ocorre no interior do ordenamento, com meios predispostos pelo próprio ordenamento (autointegração).

Portanto, a completude é uma necessidade para haver a existência do ordenamento, pois para o juiz julgar casos com base nas normas de um ordenamento, esse ordenamento deve ser completo. A fim de alcançar a completude, em sua “Teoria do ordenamento jurídico”, Bobbio (1999: p. 146$7 ; 2011)$ nos dá notícia de dois métodos de integração que Carnelutti divide em duas terminologias distintas: a heterointegração (consistindo na utilização de ordenamentos alienígenas e/ou de fontes diversas da lei positivada) e a autointegração. ${ }^{3}$ Para o objeto de estudo em análise e por ser o método escolhido por nosso ordenamento jurídico ${ }^{4}$ (LINDB, art. $4^{\circ}$, novo Código de Processo Civil, art. 140, Consolidação das Leis do Trabalho, art. $8^{\circ}$, Código de Processo Penal, art. $3^{\circ}$, Código Tributário Nacional, art. 108, Código de Defesa do Consumidor, art. $7^{\circ}$, Lei sobre arbitragem $\mathrm{n}^{\circ}$. 9.307/96, art. $2^{\circ}$ ), além de, segundo Bobbio ser o mais pertinente ao ordenamento jurídico italiano, interessa o método da autointegração o qual suporta duas vertentes: a analogia e os princípios gerais do direito.

Considerando os diplomas legais acima, percebe-se que em todas as situações, o legislador pressupôs que a lacuna deve ser preenchida com uma regra no mesmo âmbito das leis vigentes. A existência dessa norma pressupõe uma completude do ordenamento, pois o juiz deve julgar os casos a partir do próprio ordenamento e não livremente, de acordo com pressupostos próprios. $\mathrm{Ou}$ seja, para haver a completude de um ordenamento, devem-se respeitar dois grandes passos, em conjunto: 1) o juiz é obrigado a julgar todas as controvérsias que se apresentam ao seu exame; 2) o juiz é obrigado a julgá-las com base em uma norma pertencente ao sistema.

Bobbio (2008; p. 291) aduz que a autointegração do Direito ocorre principalmente mediante a interpretação analógica (analogia legis), fundada no raciocínio por analogia. Tal raciocínio, segundo o filósofo italiano, é um instrumento fundamental da jurisprudência e é reconhecido explícita ou implicitamente por todos os ordenamentos. Para que não seja admitido, é necessário que seja expressamente proibido pelo direito, o que ocorre principalmente para a lei penal (art. 14 das Disposições Preliminares do Código Civil Italiano) em homenagem ao princípio do iluminismo liberal nullum crimen, nulla poena sine lege. Ora, o positivismo jurídico sustenta que a integração 
é uma atividade puramente interpretativa, porque o raciocínio por analogia é um raciocínio lógico, isto é, um raciocínio de tipo silogístico (hoje diríamos um juízo analítico ou uma tautologia), que se limita a evidenciar certas consequências já implicitamente presentes nas premissas dadas (BOBBIO: 2008; p. 291).

No entanto, Bobbio (2008; p. 291) salienta, que para que tal raciocínio por analogia seja exato, é necessário que haja uma "semelhança relevante". No caso da interpretação analógica, quando é que, entre o caso regulado por uma norma, e o caso ao qual é estendida a disciplina de tal norma existe semelhança relevante? Bobbio (1999; p. 153-4) responde que tal semelhança (isto é, de mesmo fundamento, substância, essência) existe quando os dois casos apresentam a mesma ratio legis, é dizer, quando o elemento que induziu o legislador a dar ao primeiro caso certa disciplina jurídica se encontra também no segundo caso. A comunhão da ratio legis entre os dois casos representa, no campo do direito, aquela comunhão da razão suficiente que torna legítimo o raciocínio por analogia. Assim é que o direito dispõe ser necessário que os dois casos, aquele regulado e o "não-regulado" tenham em comum a ratio legis. A capacidade de expansão lógica do ordenamento jurídico encontra o seu fator de propulsão precisamente na ratio legis: é a ratio de uma norma que a torna capaz de disciplinar outros casos, além daqueles expressamente nela previstos (BOBBIO: 2008; p. 293, 295).

Em outras palavras, entre um fato e outro, há de ter-se um genus comum (BOBBIO: 2008; p. 295). É neste que iremos encontrar o nexo de relação de uma coisa com a outra. Estabelecido o vínculo, a consequência é a admissão jurídica de que ambos possam ocupar a mesma posição ontológico-formal em termos regulatórios de conduta.

Desse modo, como ferramenta de interpretação do direito, a analogia é o processo de positivação de uma norma que, para fins de subsunção de um fato, sem norma precisa que lhe dê tratamento, toma por pressuposto semelhança essencial entre dois suportes fáticos. O genus comum, e essencial, deste modo, justifica a própria assunção de uma ratio legis única para ambos os casos, razão suficiente para se proceder, e conferir competência ao aplicador do direito para, interpretação analógica.

Com precisão, Ferrara (1978; p. 186-7) menciona que o fundamento da analogia repousa sobre a ideia de que "os fatos de igual natureza devem possuir igual regulamento", sendo que um fato já regulado por lei pode balizar outro, desde que haja similitude entre ambos. Vale dizer, "onde se depare razão igual à da lei, ali prevalece a disposição correspondente, da norma referida" (MAXIMILIANO: 2000; p. 209).

Maria Helena Diniz (2005; p. 114), lembra, no entanto, que é necessário, "que além da semelhança entre o caso previsto e o não regulado haja a mesma razão, para que o caso não contemplado seja decidido de igual modo. Daí o célebre adágio romano: ubi eadem legis ratio, ibi eadem dispositio" (Onde existe a mesma razão, aí se aplica o mesmo dispositivo legal).

Para haver aplicação analógica, requerer-se-ia então: a) "que o caso sub judice não estivesse previsto em norma jurídica"; b) "que o caso não contemplado tenha como previsto, pelo menos uma relação de semelhança", e, c) "que o elemento de identidade entre os casos não seja qualquer um, mas sim fundamental ou de fato que levou o legislador a elaborar o dispositivo que estabelece a situação a qual se quer comparar a norma não contemplada". 
Na jurisprudência brasileira, o caso da aplicação do art. 57 da Lei no 8.213/1991 para os aposentados em regime especial, em face na inércia legislativa quanto à regulamentação do art. $40^{\circ}$, parágrafo $4^{\circ}$, da Constituição Federal, constitui um exemplo em que o Supremo Tribunal Federal utilizou a analogia para a solução da questão, preenchendo a lacuna então existente (ENGISCH: 2001; p. 294).

Destarte, quando num caso não regulado (nanotecnologia) se encontra a mesma ratio (proteção/segurança de pessoas e do meio ambiente) que funda a disciplina de outro caso (lei de biossegurança para Organismos Geneticamente Modificados; lei de descarte de resíduos sólidos; lei de acidente nuclear, os Tratados e Convenções Internacionais ratificados pelo Brasil), também ao primeiro pode ser estendida essa mesma disciplina (BOBBIO: 1995; p. 218), no tocante aos riscos e responsabilidades por danos ocasionados em decorrência da utilização/aplicação de produtos contendo nanomateriais e nanopartículas.

A integração do ordenamento jurídico via analogia legis aplicada à nanotecnologia, justifica a tese da aplicação da responsabilidade civil objetiva e agravada para responsabilização dos interessados na investigação e investimentos no setor, acompanhando a normativa brasileira de biossegurança que ao definir engenharia genética, por exemplo, adotou paradigmas semelhantes aos de outros subsistemas de responsabilidade sem culpa, a exemplo da lei de acidente nuclear valorou positivamente a atividade por si mesma, desde que autorizada e exercida por quem de direito, e proibiu, a juízo de órgãos de controle, os riscos graves para a saúde ou meio ambiente. Nisso, está aparentada ao direito do consumidor: o risco, até certa medida, é tolerado, mas transferido, quando necessária a reparação, para o explorador.

Como fundamento da responsabilidade objetiva em biossegurança, e no caso da nanotecnologia, os direitos envolvidos são literalmente vitais, são tanto quanto inesgotáveis, imprevisíveis, tanto que sua vinculação com o texto constitucional (defesa da vida, da saúde e do meio ambiente em geral) é imediata, e, portanto, prescinde-se de outros motivos (culpa): basta o dano e sua imputação à atividade do responsável. Há uma imensidão de perigos, sendo possível situá-los em categorias mutáveis, conforme o estado da arte: riscos para a biodiversidade (ambiente natural), para a integridade do patrimônio genético humano (DNA), para a vida e a saúde (diversos órgãos e componentes do corpo).

Além da analogia propriamente dita até agora considerada (analogia legis), há outro meio de interpretação integrativa com aquela afim, chamada de analogia juris, a saber, o recurso aos princípios gerais do ordenamento jurídico, são as normas jurídicas fundamentais ou generalíssimas do sistema, as normas mais gerais, que orientam todo o sistema jurídico (BOBBIO: 1999; p. 157), inclusive o internacional público, em conformidade com o artigo 38 do Estatuto da Corte Internacional de Justiça da ONU.

Para Bobbio (2011; p. 309), os princípios gerais são normas como todas as outras, pelos seguintes fundamentos: 1) São extraídos de normas, através de um processo de generalização sucessiva, somente podendo ser também normas; 2) A função para qual são extraídos é regular um caso, que é a função de uma norma. "Considerados da mesma maneira que os postulados de um sistema científico” (BOBBIO: 1999; p. 77), são os princípios dos quais derivam tanto as normas jurídicas de um ordenamento quanto a interpretação dessas mesmas normas, tornando o ordenamento um 
sistema jurídico, compreendido como uma totalidade formada necessariamente por elementos coerentes entre si (compatíveis uns com os outros) em seus inter-relacionamentos.

A analogia juris é uma forma de interpretação diferente da analogia legis, pois não se baseia no raciocínio por analogia, mas num procedimento duplo de abstração e de subsunção de uma species num genus. Segundo Bobbio (1995; p. 219-0), o processo de abstração consiste em extrair os princípios gerais do ordenamento jurídico: de um conjunto de regras que disciplinam certa matéria, o jurista abstrai indutivamente uma norma geral não formulada pelo legislador, mas da qual as normas singulares expressamente estabelecidas são apenas aplicações particulares: tal norma geral é precisamente aquilo que chamamos de um princípio do ordenamento jurídico. Uma vez formulada essa norma geral, o jurista a aplica àqueles casos que, não sendo disciplinados nas normas singulares expressas, são, no entanto abrangidos no âmbito dos casos previstos pela mesma norma geral. Nessa segunda fase, o jurista executa precisamente um trabalho de subsunção de uma species (os casos não regulados pelas normas singulares, exemplo da nanotecnologia) num genus (a categoria dos casos aos quais se refere a norma geral).

Mas Ferraz Júnior (1994; p. 223) menciona que "os princípios gerais de direito não são preceitos de ordem ética, política, sociológica ou técnica, mas elementos componentes do direito. São normas de valor genérico que orientam a compreensão do sistema jurídico, em sua explicação e integração, sendo que algumas são de tamanha importância que são expressamente contidas em lei”. Como o princípio da precaução amplamente estudado nessa pesquisa.

Bem por isso, Larenz (1978; p. 212) assevera que o juiz ficará adstrito aos princípios gerais que informam o ordenamento e à Constituição Federal, para que não se afigure uma arbitrariedade:

\begin{abstract}
[...] não se exige que o direito esteja expresso na forma de regras genéricas para que seja vinculatório, a codificação geral não pode, nunca, mesmo por pouco tempo, determinar exaustivamente o conteúdo da ordem jurídica. O juiz deve agir como descobridor e, ao mesmo tempo, conformador do direito que ele traz sempre de novo para a realidade, em um processo interminável a partir da lei, com a lei e, caso necessário, para além da lei. Não se pode dizer que nesses casos a decisão aja 'contra legem'. Na verdade, esse desenvolvimento do direito é "extra legem", no sentido de que exorbita ou restringe os fins cognoscíveis da lei, mas está de acordo com o direito; 'extra legem', mas 'intra ius'. Para que isso não leve à arbitrariedade, ao realizar o direito na decisão dos casos concretos, o juiz deve fazê-lo de acordo com os princípios fundamentais do ordenamento jurídico e com a Constituição, em suma, [...] deve poder integrar-se no 'sistema intrínseco da ordem jurídica'.
\end{abstract}

Assim que, para esse autor, a decisão de uma questão judicial que exige um juízo de valoração - e, ao final, todas elas exigem, porque o Direito é concebido aqui como uma ordem positiva de valores - pode até ser praeter legem, mas será, necessariamente, intra jus. Vale dizer, na decisão orientada por valores o juiz pode ir para além daquilo enunciado pelo texto da lei. Porém, sua decisão, que positiva valores, será de acordo com o Direito.

Mas Lenio Streck (2011; p. 518) em crítica aos princípios gerais do Direito, entende que, “enquanto os princípios gerais do Direito se constituem em uma "autorização" para discricionariedade [...], os princípios constitucionais apresentam-se, contemporaneamente, como um contraponto a essa discricionariedade". Por isso, de forma percuciente, afirma existir uma ruptura paradigmática entre os princípios constitucionais e os princípios gerais do direito. Trata-se de uma verdadeira 
descontinuidade em que os primeiros não podem simplesmente ser considerados sucedâneos dos outros.

Em suma, cabe registrar que os elementos que permeiam o conceito de princípios constitucionais, embora projetem maior luz para o fenômeno da decisão judicial, não podem ser tidos como permissivas para livre criação jurisprudencial do direito. $\mathrm{O}$ dever de fundamentação das decisões somente é plenamente satisfeito na medida em que as decisões se apresentam adequadas à Constituição. No fundo, os princípios constitucionais oferecem espaços argumentativos que permitem controlar os sentidos articulados pelas decisões. Ademais, o conteúdo dos princípios constitucionais não é pré-definido por lei, muito menos pode ser livremente determinado pelos tribunais, isso porque eles são manifestação histórico-cultural que se expressam em determinado contexto de uma experiência jurídica comum.

Reforce-se que os limites da interpretação jurídica, sem dúvida devem guardar total observância com a Constituição. Em outras palavras, a interpretação do juiz, não é a sua interpretação individualista ou simplesmente uma adequação entre significante e significado (lei e direito), taxativamente, é algo muito mais sofisticado, como diria Gadamer, e diz Müller e Streck. Deve ser a compreensão do caso concreto, como uma resposta adequada para as partes da relação processual, ou seja, como resultado do texto, a norma de decisão para o caso concreto, em especial, nesse momento, de grande tensão que, exsurgem os incontroláveis ativismos e decisionismos do intérprete, quando ocorre o deslocamento da norma de seu texto, ou seja, superando os limites do imposto pelo texto legislativo (democrático).

Como alerta Espíndola (2015), "Se antes quase não havia princípios constitucionais na cena jurídica, hoje não há princípio que baste para justificar decisões judiciais ou administrativas muitas vezes dadas sem critério metódico de aplicação".

Vale destacar que o que se convencionou chamar de "neoconstitucionalismo" no Brasil, tem como fundamento normativo a instituição, exclusiva ou preferencial, dos princípios nas Constituições do pós-guerra, de que seria exemplo a Constituição Brasileira de 1988. Para Ávila (2009; p. 17-19) “esse modelo não foi adotado, não deve ser adotado, nem é necessariamente bom que o seja, é preciso repensá-lo, com urgência". Nas palavras do autor, "O que se pode afirmar é, tão-só, que a Constituição é um complexo de regras e princípios com funções e eficácias diferentes e complementares". No entanto, aponta Daniel Sarmento (2006; p. 200), que "Muitos juízes, deslumbrados diante dos princípios e da possibilidade de, através deles, buscarem a justiça - ou o que entendem por justiça -, passaram a negligenciar do seu dever de fundamentar racionalmente os seus julgamentos. Esta 'euforia' com os princípios abriu um espaço muito maior para o decisionismo judicial".

Importa dizer, que em face das previsões legais mencionadas (em especial da LINDB e do $\mathrm{CPC}$ ), é conclusivo que o juiz não se exime de sentenciar ou despachar alegando lacuna ou obscuridade da lei. No julgamento da lide, caber-lhe-á aplicar as normas legais; não as havendo, recorrerá à analogia e aos princípios gerais do direito.

O legislador, reconhecendo a impossibilidade lógica de regulamentar todas as condutas, prescreve normas desse tipo com o escopo de estabelecer a "plenitude do ordenamento". E a proibição da denegação da justiça pelo juiz pretende tão somente estabelecer tal completude. 
Nesse contexto a integração de uma lacuna, portanto, não se situa no plano legislativo, tampouco é uma delegação legislativa ao juiz; ele não cria novas normas jurídicas gerais, mas individuais, que só poderão ascender à categoria de normas jurídicas gerais em virtude de um subsequente processo de recepção e absorção dessas normas por uma lei ou jurisprudência, uma vez que as súmulas dos tribunais são tidas, por alguns autores, como normas gerais.

O juiz cria norma jurídica individual que só vale para cada caso concreto, pondo fim ao conflito, sem dissolver a lacuna, pois o caso sub judice por ele resolvido não pode generalizar a solução para outros casos, mesmo que sejam idênticos. A instauração de um modelo jurídico geral cabe ao Poder Legislativo, bem como as modificações e correções da norma, procurando novas formas que atendam e satisfaçam às necessidades sociais.

Consideremos o magistério de Ferrajoli (2012; p. 34) que, com razão expõe "Quase todos os direitos fundamentais exigem, na verdade, leis de regulamentação idôneas para assegurar a todos as garantias primárias [...], até mesmo, o direito à vida permaneceria inefetivo, em face do princípio da legalidade penal, se não houvesse a previsão do homicídio como crime".

Resta indiscutível, portanto, que a atuação do Poder Judiciário, não deve substituir a função primária atribuída pela Constituição de 1988 ao Poder Legislativo, qual seja, de inovar o ordenamento jurídico através de leis aprovadas pelo devido procedimento legislativo-constitucional, pois no modelo do constitucionalismo juspositivista teorizado por Ferrajoli, o preenchimento de lacunas (isto é, a falta de normas) e a resolução de antinomias, (isto é, a normas vigentes, mas inválidas) nas quais elas se manifestam, não são confiados ao ativismo interpretativo dos juízes, mas somente à legislação - e, por isso, à política -, no que diz respeito às lacunas e ao anulamento das normas inválidas; e à jurisdição constitucional, no que diz respeito às antinomias.

Na visão de Ávila (2009; p. 16), o Poder Judiciário não deve assumir, em qualquer matéria e em qualquer intensidade, a prevalência na determinação da solução entre conflitos morais porque, num Estado de Direito, vigente numa sociedade complexa e plural, deve haver regras gerais destinadas a estabilizar conflitos morais e reduzir a incerteza e a arbitrariedade decorrente da sua inexistência ou desconsideração, cabendo a sua edição ao Poder Legislativo e a sua aplicação, ao Judiciário. Independente disso há, ainda, argumentos em favor da função legislativa que não podem ser considerados.

$\mathrm{Na}$ sociedade atual, em que se asseguram as variadas manifestações da liberdade, não só existe uma pluralidade de concepções de mundo e de valores, como, também, há uma enorme divergência com relação ao modo como essas concepções de mundo e de valores devem ser realizadas. Vale dizer, há divergência com relação aos valores e com referência ao modo de realização desses valores. A rigor, não há uma solução justa para o conflito e para a realização desses valores, mas soluções que precisam, por algum órgão, ser tomadas para pôr fim ao infindável conflito entre valores e às intermináveis formas de realizá-los.

Pois bem, o Poder onde, por meio do debate, se pode respeitar e levar em consideração essa pluralidade de concepções de mundo e de valores, e o modo de sua realização, é o Poder Legislativo (WALDRON: 1999; p. 124 e ss). Por meio dele é que, pelos mecanismos públicos de discussão e votação, se pode obter a participação de todos e a consideração da opinião de todos, em matérias para as quais não há uma solução, mas várias soluções para os conflitos de interesses, não um só 
caminho para a realização de uma finalidade, mas vários caminhos para a sua promoção. Esse é o caso das atividades envolvendo nanotecnologia.

Mas Ávila (2009; p. 18) assevera que não se quer, com isso, afirmar que a participação do Poder Judiciário deva ser menor em todas as áreas ou em todas as matérias, ou que a edição de uma regra, constitucional ou legal, finda o processo de concretização normativa. Como a Constituição de 1988 é composta basicamente de regras, e como ela própria atribui, em inúmeras situações ao Poder Legislativo a competência para editar regras legais, sempre que esse poder exercer regularmente a sua liberdade de configuração e de fixação de premissas dentro dos parâmetros constitucionais, não poderá o aplicador simplesmente desconsiderar as soluções legislativas, quando encontradas no exercício legítimo do princípio democrático, mesmo que com base em princípios que pretende "otimizar".

Como o Poder Legislativo edita normas gerais, e como a linguagem é, em larga medida, indeterminada, caberá ao Poder Judiciário, a imprescindível função de interpretar as regras legais escolhendo, dentre os sentidos possíveis, aquele que melhor se encaixar nos ideais constitucionais; interpretar as regras legais gerais e abstratas, adaptando-as às particularidades do caso individual e concreto, eventualmente afastando a previsão geral diante de um caso efetivamente extraordinário; interpretar as hipóteses constantes das regras legais, cotejando-as com as finalidades que lhes são subjacentes, quer as ampliando, quer as restringindo, quando elas se revelarem muito restritas ou muito amplas relativamente à sua finalidade.

Em suma, não se quer dizer que o Poder Judiciário é desimportante; quer-se, em vez disso, afirmar que o Poder Legislativo é importante. E que, como tal, não pode ser simplesmente apequenado, especialmente num ordenamento constitucional que, soube estabelecer que nada poderá ser exigido senão em virtude de lei, e de prever que todo o poder emana do povo, que o exercerá por meio de representantes eleitos ou diretamente, ainda reserva ao Poder Legislativo a competência para regular, por lei, inúmeras matérias (ÁVILA: 2009; p. 18).

Cabe dizer, a legitimidade para criação de lei específica ou alteração daquelas existentes anteriormente mencionadas, para a "lacuna estrutural legislativa" do ordenamento jurídico brasileiro quanto à matéria pertinente à nanotecnologia, é dada ao Parlamento brasileiro, ao qual é destinado difundir, ampla e democraticamente o debate entre aqueles interessados (incluindo a sociedade) no desenvolvimento da tecnologia, sempre com estrita e rigorosa observância dos direitos fundamentais constitucionais pertinentes ao tema.

Alinhando-se ao pensamento de Bobbio (1999; p. 160), sobre o estudo da completude do ordenamento jurídico, conclui-se: a primeira condição para que se possa falar de lacuna é a de que o caso não esteja regulado: o caso não está regulado quando não existe nenhuma norma expressa, nem específica, nem geral, nem generalíssima, que diga respeito a ele, quer dizer, quando, além da falta de uma norma específica que lhe diga respeito, também o princípio geral, dentro do qual poderia entrar, não é expresso.

Para Savigny (2009), “quando uma relação jurídica não encontra na lei instituto típico, é possível estabelecer, em consonância com o direito existente, instituição que a enquadre”. Entende o autor, que o direito contém a disciplina de todas as relações sociais, de forma implícita ou explícita, não havendo razão para se falar em lacunas no ordenamento jurídico. De modo que o ordenamento 
jurídico brasileiro, por exemplo, é completo justamente porque o direito oferece solução a todos os casos que são apresentados ao juiz. Não por meio de normas específicas, mas por meio da integração, que poderá ser realizada na forma do art. $4^{\circ}$ da LINDB. Ressalte-se ser esse o caso da matéria objeto em análise, à qual cabe de maneira interpretativa integrativa, aplicar a legislação análoga e os princípios constitucionais apontados.

No caso da nanotecnologia, o julgador deverá integrar o ordenamento jurídico pela via da analogia legis utilizando-se a propósito de leis como o Código Civil (responsabilidade civil objetiva), Código Penal, Lei da Política Nacional de Resíduos Sólidos, a Lei da Política Nacional do Meio Ambiente (exigir a implantação de medidas precaucionais de segurança de imediato, a fim de evitar a ocorrência de riscos), o Código de Defesa do Consumidor (direito à informação - rotulagem), a Lei de Acidente Nuclear (responsabilidade civil objetiva e agravada), a Lei de Biossegurança; além de Tratados e Convenções Internacionais, para a identificação da responsabilidade, mensuração dos parâmetros para a sanção e estabelecimento de condutas precavidas no trato para com o risco nanotecnológico, mormente pela exigência de adoção de medidas precaucionais e estrita observância do princípio constitucional da precaução e outros direitos fundamentais entre eles, a vida e a saúde.

O Código Civil Brasileiro de 2002 (artigo 931) trata do risco do desenvolvimento e estabelece que "ressalvados outros casos previstos em lei especial, os empresários individuais e as empresas respondem independentemente de culpa pelos danos causados pelos produtos postos em circulação". Portanto, em seu suporte fático se insere a nanotecnologia: o empresário responde pelos riscos gerados advindos dos produtos e serviços disponibilizados, além da observância ao emprego da propriedade com adequação ambiental contida no mesmo arcabouço legal (artigo 1.228 e $\S 1^{\circ}$ ).

Quanto aos resíduos decorrentes de nanomateriais, através do Projeto de Lei no ${ }^{\circ}$.6.741/2013 busca-se adaptar a matéria da nanotecnologia por meio da Lei da Política Nacional de Resíduos Sólidos ( $\mathrm{n}^{\circ}$. 12.305/2010). Nesse caso, conforme artigo 20 desse diploma legal, a priori, os rejeitos da nanotecnologia, quanto à periculosidade, podem ser classificados como: a) resíduos perigosos (aqueles que, em razão de suas características de inflamabilidade, corrosividade, reatividade, toxidade, patogenicidade [...] apresentam significativo risco à saúde pública ou à qualidade ambiental, de acordo com a lei, regulamento ou norma técnica, ou b) resíduos não perigosos (aqueles não enquadrados na alínea "a").

A Lei da Política Nacional do Meio Ambiente expressa no seu artigo 14 que "o não cumprimento das medidas necessárias à preservação ou correção dos inconvenientes e danos causados pela degradação da qualidade ambiental sujeitará os transgressores", sem que haja "prejuízo das penalidades definidas pela legislação federal, estadual e municipal”, a vários tipos de sanção (multas, perda/restrição de incentivos e benefícios fiscais, perda/suspensão de participação em linhas de financiamento concedidas por estabelecimentos de crédito oficiais, ou ainda, suspensão das atividades da empresa danosa) - sendo a responsabilização também considerada independente de culpa, isto é, basta o dano e sua imputação à atividade do responsável (responsabilidade objetiva).

No campo da responsabilidade objetiva, os danos ambientais têm como primeira referência obrigatória a própria Constituição Federal, que incorpora o direito ao meio ambiente ecologicamente equilibrado, como bem difuso e impõe um tripé de sanções, na esfera administrativa, penal e civil conforme disposto no seu artigo $225, \S 3^{\circ}$. 
Além da Lei de Política Nacional do Meio Ambiente e a Lei de Crimes Ambientais ( $\mathrm{n}^{\mathrm{o}}$. 9.605/1998), caberia acrescer a esse elenco de diplomas básicos outros, versando sobre danos nos seguintes contextos: atividades insalubres a trabalhadores (Consolidação das Leis do Trabalho); transporte aquaviário de mercadorias (Dec.-lei $\left.n^{\circ} .116 / 1967\right)$; atividades nucleares ( $n^{\circ} .6 .453 / 1977$ ); transporte rodoviário de produtos perigosos ( $\mathrm{n}^{\circ}$. 7.092/1983); objetos submersos ( $\mathrm{n}^{\mathrm{o}}$. 7.542/1986); recursos da zona costeira ( $\mathrm{n}^{\mathrm{o}}$. 7.661/1988); danos à fauna aquática $\left(\mathrm{n}^{\mathrm{o}}\right.$. 7.679/1988); agrotóxicos $\left(n^{\circ} .7 .802 / 1989\right)$; mineração ( ${ }^{\circ}$. 7.805/1989); atividades agrícolas ( $\left.n^{\circ} .8 .171 / 1991\right)$.

O Código de Defesa do Consumidor (Lei nº 8.078/1990) em diversos artigos (principalmente aqueles dos seus Capítulos I e IV) estabelece a responsabilização independente de culpa e a inversão do ônus da prova em favor do consumidor (hipossuficiente, ou que apresente verossimilhança em suas alegações).

A lei de responsabilidade em atividades nucleares (art. 26) consagra a responsabilidade irrestrita por danos nucleares e, em matéria de precaução, prevê a responsabilização penal daquele que, ao explorar atividade nuclear, não observar as normas de segurança relativas à instalação nuclear e ao manuseio do material nuclear.

Ainda em sua aplicação na prática jurisdicional pela analogia legis, em especial por referirem o princípio constitucional da precaução, tem-se os Tratados e as Convenções internacionais ratificados pelo Brasil antes, e após a promulgação da $\mathrm{CF} / 1988$, aplicáveis à nanotecnologia, entre eles: a Convenção de Viena para a Proteção da Camada de Ozônio (1985), a Agenda 21 (1992), a Convenção-Quadro das Nações Unidas sobre Mudança do Clima (1992), o Protocolo de Cartagena sobre Biossegurança (2000), a Convenção de Estocolmo sobre Poluentes Orgânicos Persistentes (2001), além de disposição específica sobre o tema no Protocolo de Kyoto, em vigor a partir de Fevereiro de 2012. Assim, por exemplo, pode-se aplicar para casos semelhantes e com a mesma razão de direito, o Princípio 15 da Agenda 21, que exprime de maneira clara quando o princípio da precaução deve ser aplicado. Também na experiência internacional, desde sua primeira formulação no âmbito da disciplina das chuvas ácidas (pluies acides), o princípio da precaução "foi progressivamente se estendendo do meio ambiente para a segurança alimentar e, depois da crise da vaca louca (vache folle), para a saúde pública" (PEREIRA; SILVA: 2008).

Diante de demanda judicial em que se pleiteie reparação pela comprovação de riscos e/ou causação de danos à saúde de consumidores e trabalhadores e ao meio ambiente, oriundos do processo nanotecnológico, o julgador poderá ainda, recorrer à forma integrativa do ordenamento jurídico chamada de analogia juris, caso em que aplicará os princípios constitucionais, entre os quais, o princípio da precaução (fundamentado pela obrigação geral de segurança, a reparação integral dos danos, positivados na Constituição Federal e em diversos diplomas legais de direito interno e internacional), da dignidade humana (estabelecida no inciso III do art. $1^{\circ} \mathrm{da} \mathrm{CF}$ como fundamental do Estado brasileiro), do respeito à vida, à saúde, à função social da propriedade e dos contratos, ética social, solidariedade, à igualdade substancial no plano individual e global.

Portanto, a considerar hipótese de ausência legal ("lacuna estrutural legislativa" para Ferrajoli), específica para a nanotecnologia, aponta-se ser possível a aplicação à nanotecnologia, mesmo que de forma parcial de diplomas legais, além de princípios (direitos fundamentais) constitucionais, em especial da precaução contido no $§ 1^{\circ}$, incisos IV e V, do artigo 225 da CF/1988 e na 
Lei de Biossegurança, essa que regulamentou os dispositivos constitucionais dos incisos II, IV e V, do $\S 1^{\circ}$, do referido artigo, tendo estabelecido normas de segurança e mecanismos de fiscalização, as quais devem ter como diretrizes "o estímulo ao avanço científico na área de biossegurança e biotecnologia, a proteção à vida e à saúde humana, animal e vegetal e a observância do princípio da precaução para a proteção do meio ambiente" e que, entende-se, se faz imperiosa também sua aplicação de forma ampliada para a esfera normativa da biotecnologia e da nanotecnologia em todos os seus setores, abrangendo a proteção da saúde humana e da hereditariedade.

Todavia, pelas razões vistas, considerando as especificidades que a nanotecnologia apresenta, permanece o desafio jurídico ao Estado Brasileiro em promulgar lei , ou promover a adaptação em especial de leis, como da biossegurança e de resíduos sólidos, para seu adequado descarte, a fim de regulamentar de maneira abrangente a nanotecnologia, envolvendo a geração de novas metodologias e protocolos com abordagem multidisciplinar, principalmente entre a química, responsável pela síntese, quantificação e caracterização dos materiais, a biologia e a medicina, na concepção dos ensaios e na interpretação dos resultados, a fim de se identificar e avaliar sistematicamente materiais e processos alternativos mais seguros, e com isso, antecipar os riscos potenciais de produtos e processos contendo nanopartículas.

Novas metodologias devem incorporar critérios de tamanho, forma, área de superfície, área de atividade e estrutura, além de exigir a construção de novos instrumentos de detecção, monitoramento e a caracterização adequada de nanomateriais, bem como os processos de compreensão que acontecem na superfície da nanopartícula quando em contato com os sistemas vivos, a fim de entender os possíveis efeitos toxicológicos, e, por conseguinte, contemplar as especificidades de controle e gerenciamento dos riscos em toda a cadeia produtiva e ciclo de vida de produtos e serviços contendo nanomateriais e nanopartículas (MAYNARD: 2006).

De sorte que o Legislativo brasileiro e, da mesma forma, os agentes econômicos e demais partes envolvidas no desenvolvimento e nos procedimentos de gerência e monitoramento de riscos pertinentes às inovações científicas, não podem e não detém liberdade para desrespeitar direitos constitucionais, devendo os diplomas legislativos infraconstitucionais atender à hierarquia dos bens jurídicos expostos ao nível da Carta Constitucional, e considerar os direitos atribuídos por ela aos interesses coletivos e difusos, incluindo e criando leis, programas e pesquisas, as quais promovam o desenvolvimento tecnológico, além de estabelecer mecanismos e instrumentos de controle e avaliação preventivos, durante toda cadeia produtiva de nanomateriais, visando beneficiar as pessoas e o meio ambiente.

Nessa perspectiva, Berger Filho et al. (2013) argumentam que para que o Brasil avance na criação de legislação estatal específica, para regulamentar as inovações e promover a gestão de riscos nanotecnológicos, será preciso: a) aportar mais investimentos públicos e privados para a pesquisa relacionada a riscos ambientais e à saúde humana, o diagnóstico dos riscos sociais e econômicos e a divulgação e troca de informações na sociedade; b) ampliar o debate plural que envolva uma amplitude de stakeholders ${ }^{5}$ (órgãos estatais, instituições privadas, organizações não governamentais, universidades, empresas, sindicatos, pesquisadores etc.); além de encontrar formas mais significativas para envolver o público nas decisões de governança da nanotecnologia, fator visto por muitos como fundamental para um sistema de supervisão eficaz e democrático (DAVIES et al. 2007), e para ampliar a participação ativa das instituições brasileiras nas discussões internacionais, 
no âmbito de organizações como o Enfoque Estratégico para a Gestão Internacional de Substâncias Químicas (SAICM); ${ }^{6}$ além da ISO, em especial no Grupo de Trabalho ISO-TC 229.

Sugere-se ainda, a necessidade de ser fomentada a criação e a manutenção de canais de cooperação com órgãos governamentais de países na América Latina, e em outros continentes, com atenção às informações produzidas em instituições nas quais se percebe um avanço maior no debate e desenvolvimento de marcos regulatórios e estratégias de governança dos riscos oriundos da nanotecnologia, como é o caso das agências governamentais europeias, norte-americanas e da OCDE.

\section{CONCLUSÕES}

A evolução e avanços das investigações científicas (por exemplo, a energia nuclear, a biotecnologia, a engenharia genética e a nanotecnologia) desencadearam muitas realizações, progresso e bem-estar da sociedade, porém trouxeram também tecnologias e produtos com potenciais de risco cada vez mais altos. Com promessas de avanços científicos em quase todos os setores industriais e áreas médicas, aumento da produtividade, do desenvolvimento mais sustentável e de novos empregos, contudo, como revelado pelas tecnologias de reprodução assistida e a genética, a nanotecnologia apresenta desafios sociais e de regulamentação legal (ROCO et al. 2011).

Caso os impactos sejam mal calculados, as consequências negativas serão inevitavelmente em grande escala e muito provavelmente irreversíveis. Essas preocupações desafiam, em nível global, governos, fabricantes e organizações civis a estabelecerem um sistema jurídico-legal que contemple novas metodologias de gestão e monitoramento de prováveis e alguns já comprovados riscos e danos ocorridos durante a cadeia produtiva e a pós-comercialização de inovações contendo nanopartículas e nanomateriais.

Exige-se um posicionamento do Estado e do Direito na elaboração de leis, seja no sentido de ordenar e limitar a aplicação de novos empreendimentos terapêuticos e outras aplicações, ou de punir desvios comportamentais que afetam direitos fundamentais constitucionais, a exemplo do que ocorreu com o direito social que se formou como resposta aos problemas sociais e do direito do trabalho que se tornou independente do direito civil, e a maioria dos novos setores do direito que se originou como resposta aos riscos do progresso técnico-científico: direito referente à energia atômica, à proteção contra imissões nocivas, à tecnologia genética, à proteção contra a utilização desonesta dos bancos de dados etc. (GRIMM: 2006).

Na prática, em termos jurídico-constitucionais, implica na obrigatoriedade de adoção de medidas (legais, instrumentos de avaliação e gestão de riscos) de segurança e precaução adequadas, ordenadas e antecipatórias que limitem ou neutralizem a causação de danos ao ambiente e às pessoas, cuja irreversibilidade total ou parcial gera efeitos, danos e desequilíbrios negativamente perturbadores da sobrevivência condigna da vida humana e de todas as formas de vida centradas no equilíbrio e estabilidade dos ecossistemas naturais ou transformados.

Embora as exposições de trabalhadores, consumidores e dos ecossistemas em contato com aplicações e produtos contendo nanomateriais se encontrem em contexto de significativa gravidade, e, apesar das chamadas aos governos para implementação de mudanças regulamentares, desde ajustes na legislação existente, a apelos mais extremos para moratória, no sentido de uma poste- 
rior liberação comercial (ETC GROUP: 2003; FRIENDS OF THE EARTH: 2006; 2007; 2008; MILLER: 2006; UITA: 2007) para que governos e indústrias elaborassem "regulamentos apoiados por uma abordagem preventiva" no sentido de atentar-se para a problemática gerada pela nanotecnologia, a regulamentação jurídica do uso dessa tecnologia avançou lentamente ao redor do globo.

Inobstante, identifica-se que de forma reflexa e parcial, o ordenamento jurídico brasileiro (a exemplo das leis de biossegurança, acidente nuclear, código do consumidor, código civil) oferece regulamentação à nanotecnologia, para identificação da responsabilidade, mensuração dos parâmetros, sanção e estabelecimento de condutas precavidas no trato para com o risco nanotecnológico, além da prática jurisprudencial, com a aplicação de tratados internacionais incorporados no ordenamento jurídico brasileiro, o que se fará através do processo interpretativo integrativo pela chamada analogia legis. As aplicações com nanotecnologia podem ainda ser reguladas com estrita observância dos princípios constitucionais inspiradores do sistema da analogia juris, como o princípio da precaução, da segurança, da dignidade humana, do respeito à vida e à saúde e da reparação integral de prováveis danos advindos com a utilização de produtos, processos e serviços contendo nanotecnologia.

De sorte que as partes interessadas em nanotecnologia, devem levar em consideração no momento em que empenham esforços e recursos nesse sentido, alguns parâmetros para orientar sua atividade, bem como observar o que representam para a sua atividade as externalidades da regulamentação jurídica (FORNASIER: 2014). A legislação brasileira em geral, a práxis dos Tribunais superiores e a doutrina jurídica têm demonstrado que, mesmo que não haja ainda em vigência normativas que venham tratar do risco nanotecnológico, há fundamentos mínimos que podem servir de diretriz para que o empreendedor tenha um mínimo de conhecimento daquilo que pode vir a ser alegado em seu desfavor na seara judicial: o princípio da precaução, que norteará a ação daquele que busca se precaver contra futuros danos, que, juridicamente, poderá ser responsabilizado se, além de não concretizar padrões mínimos estabelecidos, não investir em instrumentos e estratégias traduzíveis em custos de precaução.

\section{NOTAS}

1 Lesões que desde a Revolução Industrial, passaram a ser produzidas não tanto por pessoas e sim pelas máquinas. Essa situação foi agravada com a Revolução Tecnológica que lhe seguiu. Temos, agora, danos ainda mais complexos e insidiosos, como aqueles inerentes às questões ambientais.

2 Art. 225. Todos têm direito ao meio ambiente ecologicamente equilibrado, bem de uso comum do povo e essencial à sadia qualidade de vida, impondo-se ao Poder Público e à coletividade o dever de defendê-lo e preservá-lo para as presentes e futuras gerações.

3 O método da autointegração "consiste na integração cumprida através do mesmo ordenamento, no âmbito da mesma fonte dominante, sem recorrência a outros ordenamentos e com o mínimo recurso a fontes diversas da dominante" (Bobbio, 1999, p. 146-7).

4 Outros Códigos Civis, além do brasileiro, também contêm dispositivos sobre a matéria, tais como o Código suíço (art. $1^{\circ}$ ), uruguaio (art. 16), português (art. 10), espanhol (art. $6^{\circ}$, inc. $2^{\circ}$ ), argentino (art. 16), italiano (art. 12 e inc. $2^{\circ}$ das Disposições Preliminares), peruano (art. XXIII), mexicano (arts. 19 e 20) e austríaco $\left(\right.$ art. $\left.7^{\circ}\right)$ (Diniz, 1999). Daí se percebe que a analogia, o costume e os princípios gerais de direito, 
enquanto meios supletivos das lacunas, podem ser considerados praticamente universais (Redação dada pela Lei $\mathrm{n}^{\circ} 5.925$, de $1^{\circ}$ de outubro de 1973.

5 Stakeholders é uma nomenclatura estrangeira para identificar os grupos de interesses que são externos à atividade das empresas, mas são atingidos, direta ou indiretamente por ela.

6 Marco político internacional resultante dos esforços para reforçar a cooperação internacional entre governos e outras partes interessadas (como empresas e organizações da sociedade civil) com relação à segurança química.

\section{REFERÊNCIAS}

ARORA, P.; SINDHU, A.; DILBAGHI, N.; CHAUDHURY, A.; RAJAKUMAR, G.; RAHUMAN, A-A. Nano-regenerative medicine towards clinical outcome of stem cell and tissue engineering in humans. $J$. Cell. Mol. Med. 2012, 16, 9, 1991-2000.

ÁVILA, Humberto. Neoconstitucionalismo: entre a "Ciência do Direito" e o "Direito da Ciência. Revista eletrônica de Direito do Estado, número 17, janeiro/fevereiro/março 2009, Salvador. ISSN 1981-187X.

BAKAND, S; Hayes, A; Dechsakulthorn, F. Nanoparticles: a review of particle toxicology following inhalation exposure. Inhalation Toxicology, 2012, 24, 125.

BECK, U. Sociedade de Risco: rumo a uma outra modernidade. Trad. Sebastião Nascimento, São Paulo: Editora 34, 2010.

BENYUS, J. Biomimicry: innovation inspired by nature. New York: Morrow, 1997.

BERGER FILHO, A.G.; Engelmann. W. Desenvolvimento das nanotecnologias, precaução e o direito ao meio ambiente ecologicamente equilibrado, In: Princípios do direito ambiental [recurso eletrônico]: atualidades/ Org. Clóvis Eduardo Malinverni da Silveira, Caxias do Sul, RS: Educs, 2012.

BERGER FILHO, A.G.; Engelmann, W. Reflexões sobre novos rumos para a regulação das nanotecnologias, In Relações de consumo: tecnologia. [Org.] Agostinho Oli Koppe Pereira, Luiz Fernando Del Rio Horn. Caxias do Sul, RS: Educs. 2013.

BOBBIO, N. Positivismo Jurídico: lições de filosofia do direito. Trad. Márcio Pugliese. São Paulo: Ícone, 1995.

BOBBIO, N. Teoria do ordenamento jurídico. 10ª ed. Brasília: Editora Universidade de Brasília, 1999.

BOBBIO, N. Teoria geral do Direito. São Paulo: Martins Fontes, 2008.

BOBBIO, N. Teoria geral do Direito. Trad. Silvana Cobucci Leite. $3^{\text {a }}$ ed. São Paulo: Martins Fontes, 2011.

BORM, P.J. Particle toxicology: from coal mining to nanotechnology. Inhal Toxicol. 2002, 14, 311.

BURLESON, D.J.; DRIESSEN, M.D.; PENN, R.L. On the characterization of environmental nanoparticles. J. Environ. Sci. Health Part A. 2004, 39, 2707-2753.

CABRAL DE MONCADA, L.de. Lições de Direito Civil. 4ª ed. Coimbra: Livraria Almedina Editora, 1995.

CANELAS, D.A.; HERLIHY, K.P.; DESIMONE, J.M. Top-down particle fabrication: control of size and shape for diagnostic imaging and drug delivery. Wiley Interdiscip. Rev. Nanomed. Nanobiotechnol. 2009, $1,4,391-404$.

CANOTILHO, J.J.G. O Princípio da sustentabilidade como Princípio estruturante do Direito Constitucional. Tékhne, Revista de Estudos Politécnicos, 2010, 13, 7-18. ISSN 1645-9911.

CASTANHEIRA NEVES, A. Metodologia jurídica - problemas fundamentais. Coimbra: Coimbra Editora, Boletim da Faculdade de Direito - Studia Iuridica, Univ. Portugal, 1993.

CARNELUTTI, F. Teoria geral do Direito. São Paulo: Ed. Lejus, 1999. 
CHRISTENSEN, C.; CRAIG, T.; HART, S. The great disruption. Foreign Affairs, 2001, 80, 80-95.

COYLE, D. Paradoxes of prosperity. New York: Texere Publishing, 2001.

DAVIES, J.C. Managing the Effects of Nanotechnology. Woodrow Wilson International Center for Scholars. Project on Emerging Nanotechnologies, Washington DC, 2006. Disponível em http://www.wilsoncenter. org/article/managing-the-effects-nanotechnology. Acesso em Mar. 2015.

DAVIES, T; REJESKI, D. Overseeing the Unseeable, Envtl. F. Nov.-Dec, 2007, 36, 39.

DECHSAKULTHORN, F.; HAYES, A.; BAKAND, S.; JOENG, L.; WINDER, C. In vitro cytotoxicity of selected nanoparticles using human skin fibroblasts. AATEX, 2008, 14, 397.

DINIZ, M.H. As Lacunas no Direito. 5a . ed. São Paulo: Saraiva, 1999.

DINIZ, M. H. Lei de introdução ao código civil brasileiro interpretada, $11^{\text {a }}$ Edição, São Paulo: Editora Saraiva, 2005.

DONALDSON, K.; STONE, V.; TRAN, C.L.; KREYLING, W.; BORM, P.J. Nanotoxicology. Occup Environ Med. 2004, 61, 727.

DREXLER, E.K. Engines of Creation: the coming era of nanotechnology. Nova York: Anchor Books Editions, 1986.

DREXLER, E.K. The future of nanotechnology: molecular manufacturing founder and chairman, Foresight Institute. Palo Alto, Califórnia, 2006. Disponível em <http://www.eurekalert.org/context.php?contex-

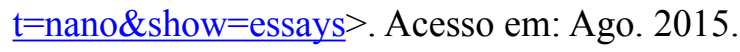

DROBNE, D. Nanotoxicology for safe and sustainable nanotechnology. Arh Hig Rada Toksikol. 2007, 58, 471.

ENGELMANN, W. As nanotecnologias e os novos direitos: a (necessária) revisão da estrutura das fontes do direito. Anuario de Derecho Constitucional Latinoamericano, 2011, año XVII, Montevideo: http://www. juridicas.unam.mx/publica/librev/rev/dconstla/cont/2011/pr/pr25.pdf, Acesso em: Mai. 2015.

ENGISCH, K. Introdução ao pensamento jurídico. 8.ed. Trad. J. Baptista Machado. Lisboa: Calouste Gulbenkian, 2001.

ESPÍNDOLA, Ruy Samuel. Princípios e retorno do pêndulo: crítica ao chamado neoconstitucionalismo. Revista Jus Navigandi, ISSN 1518-4862, Teresina, ano 20, n. 4397, 16 jul. 2015. Disponível em: https://jus. com.br/artigos/40928. Acesso em: 3 dez. 2019.

ETC GROUP. No Small Matter II: the case for a global moratorium: size matters! ETC Group. Winnipeg, Canada, Occasional paper series, 7, 1, April, 2003. Disponível em http:// www.etcgroup.org/upload/publication/165/01/occ.paper_nanosafety.pdf. Acesso em: Out. 2015.

EUROPEAN PARLIAMENT AND COUNCIL. Regulation (EC) no 1223/2009 of the European Parliament and of the Council of 30 November, 2009, on Cosmetic Products. http://eur-lex.europa.eu/legal-content/EN/ ALL/?uri=CELEX\%3A32009R1223. Acesso em Mai. 2016.

EUROPEAN PARLIAMENT AND COUNCIL. Regulation (EU) $n^{\circ} 1169 / 2011$ of the European Parliament and of the Council of 25 October, 2011, on the provision of food information to consumers. http://eur-lex. europa.eu/legal-content/EN/ALL/?uri=CELEX\%3A32011R1169. Acesso em Mai. 2016.

EUROPEAN PARLIAMENT AND COUNCIL. Regulation (EU) n $n^{\circ}$ 528/2012 of the European Parliament and of the Council of 22 May, 2012, concerning the making available on the market and use of biocidal products. http://eur-lex.europa.eu/LexUriServ/LexUriServ.do?uri=OJ:L:2012:167:0001:0123:en:PDF. Acesso em Mai. 2016.

FERRAJOLI, L. Garantismo, hermenêtica e (neo) constitucionalismo: um debate com Luigi Ferrajoli. In: Luigi Ferrajoli, Lenio Luiz Streck e André Karam Trindade. (Organizadores). Porto Alegre: Livraria do Advogado, 2012.

FERRARA, F. Interpretação e aplicação das leis. $3^{\mathrm{a}}$ ed. Coimbra: Armênio Amado, 1978. 
FERREIRA, C.W.D. A responsabilidade prospectiva como princípio implícito na ordem constitucional brasileira. Revista Direito e Liberdade, ESMARN, 13, 2, 45-70, jul/dez, 2011.

FERRAZ JÚNIOR, T.S.de. Introdução ao estudo do direito: técnica, decisão, dominação. $2^{\mathrm{a}}$ ed. São Paulo: Atlas, 1994.

FORNASIER, M. de O. Princípio da precaução e regulação do risco nanotecnológico: Consequências Econômicas, EALR, 5, 2, 296-314, Jul-Dez 2014.

FRIENDS OF THE EARTH. Australia and United States. Nanomaterials, Sunscreens and Cosmetics: Small Ingredients, Big risks, Report, May, 2006. Disponível em http://nano.foe.org.au/node/125. Acesso em Mai. 2016.

FRIENDS OF THE EARTH. Australia, International Union of Food Workers Calls for moratorium on nano in food and agriculture, 2007. Disponível em http://nano.foe.org.au/node/195. Acesso em: Mai. 2016.

FRIENDS OF THE EARTH. Australia, Europe \& United States. Out of the laboratory and on to our plates: Nanotechnology in food \& agriculture, March, 2008. Disponível em http://nano.foe.org.au/node/219. Acesso em Mai. 2016.

GRIMM, D. Constituição e Política. Trad. Geraldo de Carvalho. Coordenação e supervisão Luiz Moreira. BH, Del Rey, 2006.

HANKIN, S. M. CABALLERO, N.E.D. Regulating nanotechnology in Brazil and the European Union. Ministério da Ciência, Tecnologia e Inovação, 2014. Disponível em http://sectordialogues.org/sites/default/ files/acoes/documentos/dialogos_setoriais_nanotecnologia_portugues.pdf. Acesso em Ago. 2015.

HARPER, S.L.; CARRIERE, J.L.; MILLER, J.M.; HUTCHISON, J.E.; MADDUX, B.L.S; TANGUAY, R.L. Systematic evaluation of nanomaterial toxicity: utility of standardized materials and rapid assays. ACS Nano. 2011, 5, 6, 4688-4697.

HART, S.L.A; MILSTEIN, M.B. Global sustainability and the creative destruction of industries. Sloan Management Review, 1999, 41, 1, 23-33.

HART, S.L.A; MILSTEIN, M. B. Criando valor Sustentável, 2004, 3, 2, maio/julho.

HESSE, K. A força normativa da Constituição. Trad. Gilmar Ferreira Mendes. Porto Alegre: Sérgio Fabris, 1991.

INTERNATIONAL RISK GOVERNANCE COUNCIL. White Paper on Nanotechnology Risk Governance, no. 2. by Ortwin Renn and Mike Roco, with Annexes by Mike Roco and Emily Litten, Geneva, 2006. Disponível em https://www.irgc.org/IMG/pdf/IRGC_white_paper_2_PDF_final_version-2.pdf. Acesso em Mai. 2016.

INTERNATIONAL RISK GOVERNANCE COUNCIL. Project on nanotechnology risk governance. Policy Brief Nanotechnology Risk Governance Recommendations for a global, coordinated approach to the governance of potential risks. Geneva, 2007. Disponível em https://www.irgc.org/issues/nanotechnology/ nanotechnology-risk-governance/ acesso em Mai. 2016.

KREIDER, M.; BURNS, A.M.; DE ROSE, G.H.; PANLO, J.M. Protecting Workers from Risks Associated with Nanomaterials: Part II, Best Practices in Risk Management, Sep 01, 2013. Disponível em https:// ohsonline.com/Articles/2013/09/01/Protecting-Workers-from-Risks-Associated-with-Nanomaterials.aspx$\underline{\text { Page }=2}$

LAI, J.C.; ANANTHAKRISHNAN, G.; JANDHYAM, S.; DUKHANDE, V.V.; BHUSHAN, A.; GOKHALE, M.; DANIELS, C.K.; LEUNG, S.W. Treatment of human astrocytoma U87 cells with silicon dioxide nanoparticles lowers their survival and alters their expression of mitochondrial and cell signaling proteins. Int. J. Nanomedicine, 2010, 5, 715-23.

LARENZ, K. Metodologia da Ciência do Direito. Lisboa: Fundação Calouste Gulbenkian, 1978.

LASSALE, F. A Essência da Constituição. Rio de Janeiro: Lumen Juris, 5ª ed. 2000. 
LOUREIRO, J.C. Adeus ao Estado Social? A Segurança Social entre o Crocodilo da Economia e a Medusa da Ideologia dos "Direitos Adquiridos". Coimbra: Coimbra Editora, 2010.

MASSADA, J. UBA adverte para os malefícios da nanotecnologia, 2010. Disponível em: http://www.cienciahoje.pt/index.php?oid=36120\&op=all. Acesso em Mar. 2016.

MATHIEU, B.; VERPEAUX, M. Droit Constitutionnel. Paris: Presses Universitaires de France, 2004.

MAXIMILIANO, C. Hermenêutica e aplicação do Direito. $8^{\text {a }}$ ed. São Paulo: Freitas Bastos, 1965.

MAXIMILIANO, C. Hermenêutica e aplicação do Direito. 18 ${ }^{\mathrm{a}}$. ed. Rio de Janeiro: Forense, 2000.

MAYNARD, A.D. Nanotechnology: A Research Strategy for Addressing Risk. Washington, DC. Project on Emerging Nanotechnologies. Woodrow Wilson International Center for Scholars, 2006. Disponível em http://www.nanotechproject.org/file download/files/PEN3 Risk.pdf. Acesso em Abr. 2015.

MCDONOUGH, W.; BRAUNGART, M. Cradle to cradle. New York: North Point Press, 2002.

MCINTYRE, R.A. Common nano-materials and their use in real world applications. Science Progress, $2012,95,1$.

MILLER, G. Friends of the Earth Australia. Nanomaterials, Sunscreens and Cosmetics: small ingredients, big risks, 2006. Disponível em http://www.foeeurope.org/activities/nanotechnology/nanocosmetics.pdf. Acesso em Abr. 2016.

MONIZ, A. M. da C.P.B. Exposição profissional a nanopartículas na indústria farmacêutica - estudo exploratório. Instituto Politécnico de Lisboa. Escola Superior de Tecnologia da Saúde de Lisboa. Dissertação de Mestrado em Segurança e Higiene no Trabalho, Lisboa, 2013.

OLIVEIRA ASCENSÃO, J.de. $O$ Direito: introdução e teoria geral: uma perspectiva luso-brasileira. Coimbra: Almedina, 1991.

OSTIGUY, C., ROBERGE, B.; MÉNARD, L.; ENDO, C-A. Best Practices Guide to Synthetic Nanoparticle Risk Management. IRRST, 2009.

ORGANIZAÇÃO DAS NAÇÕES UNIDAS. Agenda 21. Rio de Janeiro: CMMED, 1992.

ORGANIZACIÓN INTERNACIONAL DEL TRABAJO. Riesgos emergentes y nuevos modelos de prevención en un mundo de trabajo en transformación. Ginebra, 2010. Disponível em http://www.ilo.org/wcmsp5/ groups/public/---ed_protect/---protrav/---safework/documents/publication/wcms_124341.pdf. Acesso em Mar. 2016.

PEREIRA E SILVA, R. A nova lei brasileira de biossegurança e o instituto da responsabilidade civil. Boletín Mexicano de Derecho Comparado, México, UNAM, año XLI, n. 122, 2008. http://www.juridicas.unam.mx. Acesso em Dez. 2014.

QUÉBEC COMMISSION DE L'ÉTHIQUE DE LA SCIENCE ET DE LA TECHNOLOGIE. Position Statement: Ethics and Nanotechnology: A Basis for Action. Québec G1V 4Z2, 2006. Disponível em http:// www.ethique.gouv.qc.ca/IMG/pdf/Avisanglaisfinal-2.pdf.

RAJ, S.; JOSE, S.; SUMOD, U.S.; SABITHA, M. Nanotechnology in cosmetics: Opportunities and challenges. Journal of Pharmacy and Bioallied Science, 2012, 4, 186-93.

RENN, O.; ROCO, M.C. White Paper on Nanotechnology Risk Governance. Geneva: IRGC, 2006.

ROCO, M.C.; MIRKIN, C.A.; HERSAM, M.C. Nanotechnology Research Directions for Societal Needs in 2020: Summary of International Study. J Nanopart Res. 2011.

ROCO, M.C.; REEN, O. Nanotechnology Risk Governance, 2012. Disponível em http://irgc.org/wp-content/uploads/2012/04/Chapter13 Nanotechnology_final.pdf. Acesso em Abr. 2015.

ROMI, R. La Charte de 1'Environnement, avatar constitutionnel? Revue du droit public \& de la science politique en France et à l'étranger, Paris, LGDJ, 2004, 6, 1486.

SANTOS, N. dos; ROMEIRO, V. Inovação tecnológica e desenvolvimento sustentável: o papel das empre- 
sas. In: Direito Ambiental e desenvolvimento sustentável. Maria Cristina Vidotte Blanco Tarrega. (Coord.). São Paulo: RCS Editora, 2007.

SANTOS, N. dos; OLIVEIRA, D.G. de. A patenteabilidade de tecnologias verdes como instrumento de desenvolvimento sustentável, 2014. Disponível em http://revista.unicuritiba.edu.br/index.php/RevJur/article/ viewFile/1051/738. Acesso em Ago. 2016.

SARMENTO, D. Livres e Iguais: Estudos de Direito Constitucional. São Paulo: Lúmen Juris, 2006.

SAVIGNY, F.C.von. Sistema del Derecho Romano actual. Alicante: Biblioteca Virtual Miguel de Cervantes, 2009.

SCHULTE, P.A; RINEHART, R.; OKUN, A.; GERACI, C.; HEIDEL, D. National Prevention through Design (PtD) Initiative. J Safety Res. 2008, 39, 115-121. Disponível em www.cdc.gov/niosh/topics/ptd/ pdfs/Schulte.pdf. Acesso em Jun. 2016.

STRECK, L.L. Hermenêutica jurídica e $(m)$ crise: uma exploração hermenêutica da construção do direito. $7^{\mathrm{a}}$. ed. Porto Alegre: Livraria do Advogado, 2007.

STRECK, L.L. Verdade e Consenso - Constituição, Hermenêutica e Teorias Discursivas: da possibilidade à necessidade de respostas corretas em Direito. $4^{\mathrm{a}}$. ed. rev., ampl. e com posfácio. Rio de Janeiro: Lumen Juris, 2011.

TARREGA, M.C.V.B; OLIVEIRA, B.de. Responsabilidade corporativa, meio ambiente e desenvolvimento sustentável. In: Direito ambiental e desenvolvimento sustentável. Maria Cristina Vidotte Blanco Tarrega (Coord.). São Paulo: RCS Editora, 2007.

UNIÓN INTERNACIONAL DE TRABAJADORES DE LA ALIMENTACIÓN, AGRÍCOLAS, HOTELES, RESTAURANTES, TABACOYAFINES.(UITA) (International Union of Food, Agricultural, Hotel, Restaurant, Catering, Tobacco and Allied Workers Associations - IUF). Principles for the Oversight of Nanotechnologies and Nanomaterials, Resolution. IUF and 43 other organizations. 2007. Disponível em http://www.iufdocuments.org/www/documents/Principles $\% 20$ for $\% 20$ the $\% 20$ Oversight $\% 20$ of $\% 20$ Nanotechnologies $\% 20$ and\%20Nanomaterials.pdf.http://www.iuf.org/w/?q=node/149. Acesso em Abril 2015.

UNITED STATES ENVIRONMENTAL PROTECTION AGENCY. 40 CFR Parts 9 and 721 [EPA-HQOPPT-2009-0686; FRL-8865-4] RIN 2070-AB27 Multi-Walled Carbon Nanotubes; Significant New Use Rule. Environmental Protection Agency. Action: Final rule, 2011. Disponível em https://www.gpo.gov/ fdsys/pkg/FR-2011-05-06/pdf/2011-11127.pdf, acesso em Maio 2016.

UNITED STATES ENVIRONMENTAL PROTECTION AGENCY. Nanotechnology White Paper. Prepared for the US EPA by members of the Nanotechnology Workgroup, a group of EPA's Sciencie Policy Council. Washington DC 20460, 2007. Disponível em http://www.epa.gov/OSA/pdfs/nanotech/epa-nanotechnologywhitepaper-0207.pdf. Acesso em Agosto 2015.

UNITED STATES NATIONAL INSTITUTE FOR OCCUPATIONAL SAFETY AND HEALTH. Prevention through Design (PtD). Plan for The National Initiative, Cincinnati, OH: U.S. Department of Health and Human Services, Centers for Disease Control and Prevention, DHHS (NIOSH) Publication n ${ }^{\circ}$. 2011-121, 2010. Disponível em http://www.cdc.gov/niosh/docs/2011-121/pdfs/2011-121.pdf, acesso em Março 2016.

UNITED STATES NATIONAL INSTITUTE FOR OCCUPATIONAL SAFETY AND HEALTH. Current Intelligence Bulletin 65: Occupational Exposure to Carbon Nanotubes and Nanofibers, DHHS (NIOSH). Abril, 2013. Disponível em http://www.cdc.gov/niosh/docs/2013-145/, acesso em Abril 2015.

UNITED STATES NATIONAL NANOTECHNOLOGY INITIATIVE. Agencies Announce Nanotechnology Signature Initiative for Water Sustainability through Nanotechnology, 2016. Nanoscale Solutions for a Global-Scale Challenge. Disponível em http://www.nano.gov/node/1577, acesso em Mai. 2016.

VANCE, Marina E; Kuiken, Todd; Vejerano, Eric P; McGinnis, Sean P; Hochella, Jr. Michael F; Rejeski, David and HULL, Matthew S. Nanotechnology in the real world: Redeveloping the nanomaterial consumer products inventory. Beilstein J Nanotechnol., 2015; 6: 1769-1780. doi: 10.3762/bjnano.6.181. Acesso Dez. 2019.

VINEY, G. As Tendências Atuais do Direito da Responsabilidade Civil. Trad. de Paulo Cezar de Mello. In: 
Direito Civil Contemporâneo: Novos Problemas à Luz da Legalidade Constitucional. Tepedino, Gustavo (Org.). São Paulo: Atlas, 2008.

WALDRON, Jeremy. The Dignity of Legislation. Cambridge: CUP, 1999.

WINTER, G. European Environmental Law: A Comparative Perspective. Aldershot: Dartmouth Publishing Co. 1996, p. 39-41.

WOODROW WILSON INTERNATIONAL CENTER FOR SCHOLARS. Nanotechnology \& Regulation: A Case Study using the Toxic Substance Control Act (TSCA). A Discussion Paper, 2003.

\section{DOCUMENTOS ELETRÔNICOS}

ALEMANHA. Nanopartículas podem trazer riscos à saúde, alerta agência ambiental Alemã. 23/10/2009. Revisão: Roselaine Wandscheer. Disponível em http://www.dw.com/pt/nanopart\%C3\%ADculaspodem-trazer-riscos- $\% \mathrm{C} 3 \% \mathrm{~A} 0$-sa $\% \mathrm{C} 3 \%$ BAde-alerta-ag $\% \mathrm{C} 3 \% \mathrm{AAncia}$-ambiental-alem $\% \mathrm{C} 3 \% \mathrm{~A} 3 / \mathrm{a}-$ 4816328?maca=bra-uol-all-1387-xml-uol. Acesso em Dez. 2019.

BRASIL. Instituto Nacional de Propriedade Intelectual. Patentes Verdes. Indicadores quantitativos do projeto piloto. Disponível em http://www.inpi.gov.br/menu-servicos/patente/arquivos/patentes-verdes_09junho2015 pptx.pdf. Acesso em Dez. 2019.

BRASIL. Ministério da Ciência, Tecnologia, Inovações e Comunicações. Comitê Interministerial de Nanotecnologia aprova adesão ao NanoReg. 26/08/2014. Disponível em http://www.brasil.gov.br/cienciae-tecnologia/2014/08/comite-de-nanotecnologia-aprova-adesao-do-brasil-ao-nanoreg. Acesso em Dez. 2019.

BRASIL. Supremo Tribunal Federal. Recurso Extraordinário 627.189 São Paulo, Voto do Senhor Ministro Dias Toffoli (Relator). 08/06/2016 Plenário. Disponível em http://s.conjur.com.br/dl/aplicacao-principioprecaucao.pdf. Acesso em Dez. 2019.

EUROPEAN UNION. National Institute for Public Health and the Environment Ministry of Health, Welfare and Sport. NANoREG Results Repository. Disponível em http://www.nanoreg.eu/, acesso em Dez. 2019.

UNITED KINGDOM ROYAL SOCIETY AND ROYAL ACADEMY OF ENGINEERING. Nanoscience and nanotechnologies: opportunities and uncertainties. Science Policy Section, The Royal Society, London, UK, SW1Y 5AG, 2004. Disponível em http://www.raeng.org.uk/publications/reports/nanoscience-andnanotechnologies-opportunities, acesso em Ago. 2014.

UNITED STATES. National Nanotechnology Initiative. What Is Nanotechnology? Disponível em http:// www.nano.gov/html/facts/whatIsNano.html. Acesso em Dez. 2019.

Data de submissão do artigo: Fevereiro de 2019

Data de aceite do artigo: Novembro de 2019 